Published in Journal of the Academy of Marketing Science (2011), 39, 846-869

Final Word copy provided to journal for typesetting

\title{
Customer Experience Quality: An exploration in business and consumer contexts using repertory grid technique
}

Fred Lemke, Moira Clark and Hugh Wilson

\begin{abstract}
This study proposes a conceptual model for customer experience quality and its impact on customer relationship outcomes. Customer experience is conceptualized as the customer's subjective response to the holistic direct and indirect encounter with the firm, and customer experience quality as its perceived excellence or superiority. Using the repertory grid technique in 40 interviews in $\mathrm{B} 2 \mathrm{~B}$ and $\mathrm{B} 2 \mathrm{C}$ contexts, the authors find that customer experience quality is judged with respect to its contribution to value-in-use, and hence propose that value-in-use mediates between experience quality and relationship outcomes. Experience quality includes evaluations not just of the firm's products and services but also of peer-to-peer and complementary supplier encounters. In assessing experience quality in B2B contexts, customers place a greater emphasis on firm practices that focus on understanding and delivering value-in-use than is generally the case in B2C contexts. Implications for practitioners' customer insight processes and future research directions are suggested.
\end{abstract}

Keywords: Customer experience, repertory grid, service quality, service-dominant logic 


\section{Introduction}

As services account for an increasing proportion of gross domestic product in developed economies, it has been argued that goods are becoming commoditized and that differentiation is increasingly obtained through service (Reinartz and Ulaga 2008), although the evidence on this point is mixed (Neely 2008). A parallel argument particularly prevalent in practitioner literature (Meyer and Schwager 2007; Schmitt 1999; Shaw 2002) states that service, too, is increasingly commoditized, and that the contemporary consumer demands more than just competent service, seeking experiences which are "engaging, robust, compelling and memorable" (Gilmore and Pine 2002, p. 10).

This argument, also, is largely conjectural, but increasing academic attention is being paid to whether and how the customer experience might go beyond service. One line of work uses the metaphor of the customer journey to explore experience, defining experience as service perceptions through each touchpoint with the firm (Swinyard 1993). Other scholars use the same metaphor to argue that this journey may both precede contact with the firm and continue after contact, to include what Payne et al. (2008) term the "communication encounter" and the "usage encounter" as well as the "service encounter." The customer may perceive value processually through any part of this journey, including those parts outside the firm's direct control (Verhoef et al. 2009). Hence, the firm's role is to deliver a value proposition rather than to deliver value, which is co-created when the customer uses the firm's products and services (Vargo and Lusch 2004). As it is assumed that customers assess this expanded experience holistically (Verhoef et al. 2009), holistic frameworks for customer experience have been proposed (Grewal et al. 2009; Payne et al. 2008; Verhoef et al. 2009), leading to calls for similarly holistic empirical examinations of customer experience (Verhoef et al. 2009, Voss et al. 2008). 
In this article, we draw on service-dominant logic to argue that customers appraise their experience with respect to its perceived contribution to value-in-use-the customer's functional and/or hedonic outcome, purpose or objective that is directly served through product/service usage (Macdonald et al. 2009). We propose the concept of customer experience quality, which we define as a perceived judgment about the excellence or superiority of the customer experience. We then explore how customers construe customer experience quality, through interviews in both business-to-business (B2B) and business-toconsumer (B2C) contexts. We use the repertory grid method (Goffin 2002; Kelly 1963), which helps to uncover or "surface" (Smith 1995) complex tacit perceptions.

This exploration has three objectives: First, we validate our theoretical argument that customers construe experience quality and not just product and service quality. We find that in both B2B and B2C contexts, customers can articulate a rich set of constructs across their communication, service and usage encounters, by which they judge the excellence or superiority of their customer experience. We hence confirm speculations that customers assess their experience holistically, and we add that this assessment includes a judgment of the quality of this experience. Practitioners may conclude that their market research processes need to uncover this holistic experience quality perception; our use of repertory grid method provides a possible model for achieving this in specific product/service categories.

Our second objective is to develop a conceptual model of customer experience quality, and hence to refine existing conceptual models for customer experience which have been proposed both in conceptual studies (Grewal et al. 2009; Verhoef et al. 2009) and in studies which elicit the supplier's perception rather than the customer's (Payne et al. 2008; Voss et al. 2008). Our conceptual model confirms the role of other customers in co-creating experience and adds the role of other actors whose resources are also integrated by the customer through the emergent category of network quality. Our model also extends a 
number of previous models in positioning customer experience quality as leading to relationship outcomes such as satisfaction and retention not directly but via the mediator of value-in-use. This carries implications for both scholarly research and practitioner market research.

Our third objective is to explore whether there are differences in the construction of customer experience quality in B2B and B2C contexts, as a first step toward the contextspecific exploration of customer experience quality. We find that particularly in $\mathrm{B} 2 \mathrm{~B}$ contexts, customers assess the extent to which a supplier focuses on understanding and delivering value-in-use - that is, whether the supplier elicits and endeavors to deliver not just the product/service attributes that the customer seeks, but also the customer's own objectives from using these products/services. Verhoef et al. (2009, p. 33) suggest that "an important research opportunity is to develop a scale that aims to measure the customer's retail experience in its full detail." While this study may aid in such scale development, the context specificity we report suggests that scales may need to be similarly context specific.

The structure of the paper is as follows. We first conceptualize customer experience and customer experience quality. Next, we review existing conceptual models of customer experience, and discuss differences in literature on B2B and B2C customer experience. We then explain our application of the repertory grid method and present our results. We derive a model for customer experience quality and compare our findings in B2B and B2C contexts. Finally, we discuss implications for practitioners and suggest research directions.

\section{From service to experience}

The phenomenological nature of customer assessments of quality has been commonly accepted at least since Zeithaml (1988) discussed perceived product quality. Defining quality as a perceived judgment about an entity's overall excellence or superiority, she proposed product quality as an antecedent of perceived value and hence of outcomes such as purchase. 
In both earlier and much subsequent work, service quality has been similarly defined and empirically investigated (Parasuraman et al. 1985, 1988; Zeithaml et al. 1996).

Although Zeithaml (1988) conceived of quality as a global assessment, service quality research has received some criticism for focusing largely on transaction specific assessment (Voss et al. 2008). The notion of the customer journey is a prevalent one in service design (Voss et al. 2008). It leads to the observation that the customer's perception may vary as the journey is made (Berry et al. 2002) — a meaning of customer experience that is consistent with the definition of service quality, but which refines its commonly static measurement. Cowley (2008), for example, demonstrates that service encounters may be viewed retrospectively as more positive in order to rationalize a desired repeat purchase. Going beyond the notion of service quality, though, is the observation that this journey may both precede the service encounter and continue after it (Berry et al. 2002). Meyer and Schwager (2007), for instance, define customer experience as customers' internal and subjective response to any direct or indirect contact with the company across multiple touch points. Gentile et al. (2007, p. 397) state that: "The customer experience originates from a set of interactions between a customer and a product, a company, or part of its organization, which provoke a reaction. This experience is strictly personal and implies the customer's involvement at different levels (rational, emotional, sensorial, physical, and spiritual)."

Prior to purchase or service delivery, this "direct or indirect contact" includes the experience of marketing communications (Brakus et al. 2009) and the vicarious experience of other customers through word of mouth (Kwortnik and Ross 2007), as well as the contextual experience of approaching the company, such as the journey to a store (Gilmore and Pine 2002) or the encounter with the web medium within which a website is located (Sautter et al. 2004). Contact with the physical environment provided by the company also forms part of 
this customer journey (Pullman and Gross 2004), expanding on the tangibility dimension of service quality.

Indirect contact after the service encounter includes the consumption experience, in which customers apply the product or service to meet their goals (Woodruff 1997). While not always temporally distinct from firm touchpoints in service contexts, consumption experience is hence conceptually distinct from the judgment of service quality, which forms a judgment about the firm's processes and not the customer's (Payne et al. 2008). As the customer's goals are only met as a result of the consumption process, customers can be regarded as cocreators of value (Vargo and Lusch 2004). A specific form of co-creation present in some contexts is co-production, or participation in the product/service design process (Fang et al. 2008). Another is contact with other customers in the consumption process (Arnould and Price 1993; Grove and Fisk 1997).

Customer experience, then, encompasses "the total experience, including the search, purchase, consumption, and after-sale phases of the experience" (Verhoef et al. 2009, p. 32). In particular, it "is created not only by those elements which the retailer can control ... but also by elements that are outside of the retailer's control (e.g. influence of others, purpose of shopping)" (Verhoef et al. 2009, p. 32). Building on this and the previously cited definitions, we define customer experience as the customer's subjective response to the holistic direct and indirect encounter with the firm, including but not necessarily limited to the communication encounter, the service encounter and the consumption encounter.

Our earlier quotation from Gentile et al. (2007) makes the point that this response may be multifaceted: "cognitive, affective, emotional, social and physical," as Verhoef et al. (2009, p. 32) delineate it. This raises many potential areas for research, of which in this article we explore one that lies primarily within the cognitive domain. We are inspired by the rich research into service quality, both as a lens for the understanding of customer behavior and as 
a practical tool for managers, to ask: does customer experience, too, have a perceived excellence or superiority? That is, do customers perceive customer experience quality?

\section{From product and service quality to customer experience quality}

The common definition of the quality of a product or service as a perceived judgment about its excellence or superiority (Caruana et al. 2000; Parasuraman et al. 1988; Zeithaml 1988) has raised debate as to how customers make this judgment. The contention that we judge excellence by comparing performance on product/service quality dimensions against expectations has been one much explored approach (Parasuraman et al. 1985, 1988; Zeithaml et al. 1996). A less frequent but persistent stream has argued that quality does not lead to outcomes such as purchase directly, but rather, indirectly via a value perception (Bolton and Drew 1991; Caruana et al. 2000; Oliver 1999; Sweeney and Soutar 2001).

Recent work has argued that, in any case, value is not embedded in a product at the moment of exchange but, rather, is obtained through use processes (Tynan et al. 2010; Vargo and Lusch 2004). Hence quality assessed at the factory gate is an embedded-value measure, necessary but not sufficient for value to be obtained in use (Grönroos 2000, p. 140; Woodruff and Flint 2006). We extend this argument to service quality, which at least as typically operationalized can be seen as an embedded-value measure: the service may be applied in a subsequent use process, as in the use of knowledge acquired on a course (Oliver 1999, p. 46), or a patient following advice by a medical clinician (McColl-Kennedy et al. 2009). Even in contexts such as entertainment where hedonic utility contemporaneous with service delivery predominates, this utility may arise due to multiple contextual factors such as the presence of other customers, and hence cannot be viewed as solely created by the service firm (Pullman and Gross 2004; Schembri 2009). Given that our definition of customer experience includes this usage process, we might expect customer experience quality to contribute to a fuller 
understanding of value co-creation, and hence to link more strongly to customer relationship outcomes, than product and service quality alone.

\section{Customer experience quality and value-in-use}

This argument for the nature and role of customer experience quality still begs the question: do customers construe customer experience quality? That is, do they perceive the excellence or superiority of their customer experience? This is an empirical question, but drawing on insights by Macdonald et al. (2009), we look to goal theory to throw light on what we might expect. A customer's goals “determine the relative salience of product and retailer features" (Puccinelli et al. 2009, p. 17), so customers notice what has meaning for them (Woodruff and Flint 2006, p. 188). This meaning arises from the presence of these features in a goal hierarchy, which relates "concrete goals" such as the desire for a bicycle of a particular specification to more "abstract goals" such as a desire to be able to cycle in woodlands (Barsalou 1991; Peterman 1997). In essence this goal hierarchy hypothesizes a causal link between what a supplier has to offer and the customer's goals - the concept of attribution (Raghubir and Corfman 1999). The desired customer experience and the customer's evaluation of the actual experience depend on these goals; a shopping trip for ingredients for dinner, for example, will be judged against its contribution to this goal (Rohm and Swaminathan 2004). In this sense, for services as for products, people buy performances (Deighton 1992).

These "abstract goals" constitute the value we seek from engagement with the supplierthat is, the value-in-use (Vargo and Lusch 2004). Hence, Macdonald et al. (2009), drawing on Woodruff (1997) and Woodruff and Flint (2006), define value-in-use as a customer's functional and/or hedonic outcome, purpose or objective that is directly served through product/service usage. By contrast, "concrete goals" concerning product attributes (such as the specification of a bicycle) or service attributes (such as the timeliness of the shopping 
expedition for dinner) correspond to the notion of embedded value-performance against product/service attributes for which the customer is prepared to pay (Woodruff 1997). The customer is prepared to pay for these attributes precisely because of the causal link hypothesized by the customer between these attributes and achievement, in due course, of value-in-use (Oliver 1999; Woodruff and Flint 2006).

We note that value-in-use may be utilitarian, hedonic or a mixture of the two in nature (Chitturi et al. 2008). We also note that since value-in-use is phenomenological (Vargo and Lusch 2004), it is inherently processual (Woodruff and Flint 2006), potentially varying over time through the customer journey. For example, while some abstract goals relate to outcomes subsequent to firm interaction processes, such as cooking a nice meal or having a refreshing woodland bicycle ride, others relate to the interaction process itself; for example, shopping may meet needs including entertainment, recreation, social interaction and intellectual stimulation (Arnold et al. 2005; Puccinelli et al. 2009).

The customer, then, perceives a causal link between, on the one hand, their "concrete goals" relating to product and service quality, and on the other, their outcomes, purposes or objectives which we term their value-in-use. We have, however, observed that this value-inuse is dependent not just on product and service quality but also on other aspects of the customer experience such as peer-to-peer interaction and product/service usage. It hence seems plausible that the customer may have concrete goals for these wider aspects of experience, and that the customer's goal hierarchy may similarly link these experience quality attributes to the value-in-use sought. Furthermore, if goal hierarchies relating to product/service attributes can be surfaced through such techniques as repertory grid and triadic sorting (Goffin 2002; Zeithaml 1988), it also seems plausible that the wider goal hierarchy relating to customer experience may be similarly elicitable. 
Hence, following Zeithaml's (1988) definition of quality, we define customer experience quality as a perceived judgment about the excellence or superiority of the customer experience. We defined customer experience earlier. We adopt Macdonald et al.'s (2009) definition of value-in-use cited above. Our interest in experience as occurring processually across the customer's encounter with the firm leads us to take a process perspective on the definition of service, as opposed to one by exclusion from goods (Deighton 1992; Tuli et al. 2007). Specifically, following Vargo and Lusch (2008) and consistent with Woodruff and Flint (2006), we define service as the process of using one's resources for the benefit of another entity, and product as a package of service offered by a provider to a customer as the basis of exchange. We note that part, all or none of this package may be distributed through the mechanism of goods (foundational premise 3 in Vargo and Lusch 2004).

The first objective of the exploration of customer experience quality which follows is to validate this theoretical argument that customers construe experience quality, and not just product and service quality, by eliciting customer experience quality perceptions across a sample of B2B and B2C customers. The second objective is to develop a holistic conceptual model of customer experience quality; next, therefore, we review the extant conceptual models of holistic customer experience.

\section{Existing holistic models of customer experience}

Four models of customer experience have been recently proposed (Grewal et al. 2009; Payne et al. 2008; Verhoef et al. 2009; Voss et al. 2008). They share the perspective that customers assess their journey with the firm holistically, and also concur in arguing that empirical research has to date focused on specific elements of this journey in isolation. Verhoef et al. (2009) review the separate literatures on brand experience, service experience and the experience of the in-store social environment, concluding that "the next stage of research should focus on a richer conceptualization of the customer experience ... an important 
research opportunity is to develop a scale that aims to measure the customer's retail experience in its full detail" (p. 33). Grewal et al. (2009) also review the fragmented work on retail experience under the headings of promotion, price, merchandise, supply chain and location. The retailing emphasis of both leads to a concentration on the communication and service encounters and the exclusion of the usage encounter, except for peer-to-peer processes within the store itself. While Payne et al. (2008) argue that, rather, the customer journey should be designed and assessed holistically across the communication encounter, the service encounter and the usage encounter, their illustrative case study data in the travel sector draws purely on the supplier's design perspective and not on the customer's. Voss et al. (2008) similarly take a design perspective in their data drawn from interviews with managers in service firms.

This design perspective leads to discussion in each of these contributions as to which processes are visible to the customer and which are not, or in Voss et al.'s (2008) metaphor, which are onstage and which offstage. A point of difference is that supply chain management appears only in the framework of Grewal et al. (2009), who argue that while it is important in such matters as sourcing private label goods consistent with the retailer's CSR policies, supply chain management occurs at the back end of the store.

The outcome of customer experience is not a major focus in these models, which differ in their treatment of it. Verhoef et al. (2009) describe experience as involving "cognitive, affective, social and physical responses to the retailer" without further elaboration. Grewal et al. (2009) focus purely on behavioral outcomes such as retention, cross-buying and word-ofmouth. Voss et al. (2009, p. 248) add customer-perceived value, which they describe as arising from goods, services and other experience factors assessed against expectations. They regard customer-perceived value as being "captured in terms of customer purchasing, loyalty, and engagement behaviors." This seems in practice to be close to Grewal's (2009) 
conception. Payne et al. (2008, p. 88) add customer learning, including what they term "proportioning," in which customers "reflect on their own processes ... in terms of how the value proposition relates to their lives, objectives and aspirations." This concept echoes our earlier discussion of the relationship between customer experience and value-in-use.

Some of these differences arise from the differing contexts of these models. While all respond to calls to widen experience research beyond very high involvement "peak experience" contexts (e.g. Schouten et al. 2007), Verhoef et al. (2009) and Grewal et al. (2009) restrict themselves to retailing and Voss et al. (2008) to B2C service. Only Payne et al. (2008) propose a generic model across business and consumer sectors. This raises the question of whether differences can be expected between experience in B2B and B2C contexts, which we examine next.

\section{Contrasting B2B and B2C experience}

While B2B literature under the experience banner is rare, some parallel themes concerning how customers assess their total interaction with a supplier have been explored. One theme focuses on the bundling of goods and related services into solutions (Bowman and Narayandas 2004; Tuli et al. 2007) or product-service systems (Neely 2008) in an effort to access increased profit pools. While much of this work takes the supplier perspective (e.g. Neu and Brown 2005), some has examined customer perceptions. Extending the serviceprofit chain, the product-service solution has been linked to behavioral outcomes via the mediator of overall satisfaction (Bolton et al. 2008; Bowman and Narayandas 2004). Qualitative work adds the insight that while suppliers tend to conceive value as being created purely through the delivery of the product-service bundle, their customers add to this a strong emphasis on the customer journey, from requirements definition through solution customization and integration to deployment and post-deployment support (Macdonald et al. 2009; Tuli et al. 2007). This has close parallels to B2C work on the customer journey (Payne 
et al. 2008; Voss et al. 2008), albeit with more emphasis on utilitarian outcomes (Briggs and Grisaffe 2010; Palmatier et al. 2008) and less on hedonic ones (Pullman and Gross 2004).

In both $\mathrm{B} 2 \mathrm{~B}$ and $\mathrm{B} 2 \mathrm{C}$ contexts, research into relationship quality extends this process focus beyond the boundary of a single contract (Palmatier et al. 2008). Relationship quality requires cooperative intentions, transparency and intensive follow-up contact (Dorsch et al. 1998) and is valued by the customer as it can provide confidence, social and special treatment benefits (Gwinner et al. 1998). Business customers may also perceive relationship benefits from improved innovation (Walter et al. 2003). Relationship quality varies in importance, however: in a B2B context, the customer's relationship orientation moderates the impact of relationship quality on outcomes (Briggs and Grisaffe 2010; Palmatier et al. 2008), just as consumers differ in their desire for relationship (Gwinner et al. 1998). Similarly, relationship quality is more important to customers in some sectors than others (Gwinner et al. 1998), and in particular relational firm behaviors are on average more prevalent in B2B contexts than B2C ones (Coviello et al. 2002).

Our third objective is therefore to explore whether there are differences in the construction of customer experience quality in B2B and B2C contexts. This represents a first step towards the context-specific exploration of customer experience quality, as the parallel with service quality as well as our discussion above would suggest that variations in customer experience quality across multiple contexts are likely.

\section{Method}

Sample

We use a convenience sample of 40 respondents, split evenly between B2B and B2C (see Table 1). Respondents were residents in the UK, where interviews were conducted. B2C respondents cover a spread on age and gender, as well as on socio-economic grouping, ranging from higher managerial and professional occupations to unskilled or not working 
adults. They were recruited from within a ten-mile radius of two business schools located in the UK. B2B respondents come from a range of industry sectors (goods sectors such as automotive and brewery, and services sectors such as transport and catering) and organizational functions. They were recruited from past attendees of executive courses at the same business schools; they were qualified to ensure they had extensive experience of dealing with suppliers. Interviews, which were conducted face-to-face, ranged from 40 to 90 minutes each, totaling approximately 34 hours of material. Table 1 includes a code for each respondent; these codes are used in quotations in the remainder of this article.

\section{Insert Table 1 about here}

\section{Repertory Grid Technique}

Interviews used repertory grid technique, a form of structured interviewing originating from Kelly's (1955, 1963) Personal Construct Theory, which aids in breaking complex personal views into manageable sub-components of meaning. The technique originally derived from psychology and anthropology and is particularly useful for exploring topics where the respondent knows the answer indirectly and tacit knowledge cannot be conveyed directly (Brown and Detoy 1988; Burr and Butt 1992; Goffin 2002; Hussey and Hussey 1997). Experiences exist at a conscious and unconscious level (Joy and Sherry 2003), and hence eliciting the constructs by which customer experiences are judged appears to be one such topic where knowledge is partially tacit; in two studies of manufacturer-supplier relationships, Lemke et al. (2003) and Szwejczewski et al. (2001) found that repertory grid technique resulted in a greater depth of construct elicitation than did direct semi-structured questioning alone. The technique is also valuable in management research for avoiding the use of jargon and minimizing social desirability bias (Goffin 2002; Szwejczewski et al. 2005). 
Our operationalization closely followed that of Goffin et al. (2006). Each respondent was asked to name nine suppliers in the B2B context, or "companies you deal with" in the case of B2C respondents: three with whom they had had a good experience, three a poor one, and three an average one. While some research focuses on positive experiences (Arnould and Price 1993; Frow and Payne 2007; Schouten et al. 2007) and other work concentrates on negative ones (Smith et al. 1999; Tax et al. 1998; Ward and Ostrum 2006), a spread is desirable for eliciting the constructs by which quality is judged (Goffin et al. 2006). The choice of nine suppliers, or "elements" in repertory grid terminology (Brown and Detoy 1988; Smith 1995), was guided by Tindall (1994), who regarded more than ten elements as unmanageable. Each of these supplier names was written on a numbered card (in a randomized order).

Following Kelly's $(1955,1963)$ triadic method, the interviewer then presented three cards to the respondent, asking: "In what way are two of these three similar to each other and different from the third in terms of the experience you have with them?" This resulted in a construct that the interviewer wrote on a form called a repertory grid, illustrated in Table 2 . In this sample B2B interview, this first construct was "Defined processes" (see the row numbered 1). Each construct consists of a construct pole (e.g., "Clearly defined process") and a contrast pole (e.g., "Not clearly defined process"), following the advice of Levy and Dugan (1956, p. 53), who recommend that the respondent is "then asked to indicate what he feels to be the opposite of the construct he has just listed." After the meaning of this first construct had been discussed, the respondent was asked to rate all nine suppliers (not just the three named on the cards which had been initially shown) on this construct, using a 5-point Likert scale (Fransella and Bannister 1977; Gammack and Stephens 1994). So, for example, the respondent in Table 2 was asked to rate all nine suppliers on a scale of 1 to 5 , where 1 
represented a "clearly defined process" and 5 represented a "not clearly defined process," so producing the scores in the row 1 of the grid.

\section{Insert Table 2 about here}

Next, the interviewer presented another set of three cards and restated the question, while asking the respondent not to repeat a construct which had already been given. In this example, this second triad elicited the construct "Good value for money." This process continued until the respondent could identify no further constructs, or until the time allocated for the interview had elapsed. The constant showing of a fresh set of three cards ensures variation in experience (Bender 1974); as each new triad elicits at least one new construct, the process helps respondents to uncover constructs which they may not have been consciously aware of prior to the interview. In this example grid, fourteen constructs were elicited.

\section{Data Analysis}

The analysis, as with the interview protocol, closely followed Goffin et al. (2006):

Standardization of construct names Some constructs appeared in more than one interview. The grids and transcriptions were examined by three researchers to identify such repetitions and define standardized construct names. For example, 18 respondents reported the issue of fulfilling promises by citing constructs with construct poles such as "keep promises," "deliver on the promise," and "match the promise," and contrast poles of "fail to deliver on the promise," "do not keep the promise" and "fail to meet the promise"; these were noted as instances of the construct "Promise fulfillment." This process reduced the 386 grid rows elicited across the 40 interviews to 119 constructs.

Categorization of constructs These 119 constructs were categorized into 17 experience categories, using multiple coders and inter-coder reliability checks, reported in full below. 
Identification of key constructs The most important constructs in both the $\mathrm{B} 2 \mathrm{C}$ and $\mathrm{B} 2 \mathrm{~B}$ contexts were identified, taking into account frequency count and average normalized variability, as described below.

\section{Results}

The full construct listing is displayed in Table 3. Some constructs were mentioned in only the $\mathrm{B} 2 \mathrm{~B}$ or the $\mathrm{B} 2 \mathrm{C}$ context, while others emerged in both; this is indicated in the two columns on the right. The constructs were grouped into categories, based on a connection between constructs through meaning, which were arrived at by closely following the steps of Goffin and Koners (2011) as well as Jankowicz (2004): "identifying categories," "allocating constructs to those categories," "tabulating the results," and "establishing the reliability of the category system."

\section{Insert Table 3 about here}

Specifically, the 119 constructs were first written on separate cards (showing the name of the construct, the two poles, and an illustrative quotation from the data). Where further clarification of construct meaning was required, coders also used a 46,000 word table listing the transcript portions in which each construct was discussed, with an average of around 380 words of quotation per construct. Categorization proceeded as follows:

1. The initial categorization of these cards was the outcome of an extended workshop involving the three authors who had collected data (the primary research team). Each category was named and defined. A scholar who was not involved in data collection (Coder 1) also categorized the cards independently. An inter-coder reliability index was computed showing the level of agreement of the two categorizations. The index was $50 \%$, as the two categorizations agreed on the allocation of 96 of the 193 constructs. The primary research team and Coder 1 discussed differences and agreed on a revised allocation of constructs to categories and revised category definitions. 
2. A second independent scholar, Coder 2, was given the construct cards, along with a list of category names and definitions, and asked to allocate cards to categories. An inter-coder reliability index between the coder and the categorization resulting from step 1 was 63\%. Again, the primary research team and Coder 2 discussed differences, and agreed on amendments to the allocation of cards to categories and to category definitions.

3. This process was repeated for a third independent scholar, Coder 3, resulting in an inter-coder reliability index of $71 \%$.

4. Finally, the process repeated with Coder 4 , resulting in an index of $79 \%$. This final categorization is reported in Table 3.

Key constructs were identified in both B2B and B2C contexts, using the methodology of Lemke et al. (2003) and Goffin et al. (2006), and are listed in Tables 4 and 5. To qualify as a key construct, a construct must pass a threshold for both frequency and variability. The frequency threshold is that the construct must be mentioned by at least $25 \%$ of respondents (Lemke et al. 2003) — that is, 5 of the 20 respondents in both the B2B and B2C contexts. The variability threshold is on the basis that a wide spread of ratings for a construct suggests that it may enable good, bad and average experiences to be distinguished. Average normalized variability (ANV), calculated using the FlexiGrid 6 package, is used as a measure of variability; for details of its calculation and rationale, see Goffin et al. (2006). The variability threshold is that a key construct must have an above-average ANV. In this sample, this corresponded to an ANV of 10.36.

Insert Table 4 about here

Insert Table 5 about here 


\section{Discussion}

The objectives of the study were to validate the theoretical argument that customers construe experience quality and not just product and service quality; to develop a holistic conceptual model of customer experience quality; and to explore whether there are differences in the construction of customer experience quality in B2B and B2C contexts. 119 constructs by which customers construe experience quality were identified, and categorized into 17 experience categories, shown in Table 3. We derive a holistic conceptual model of customer experience quality in Figure 1; this model, the derivation of which we describe below, confirms the role of other customers in co-creating experience, and adds the role of other actors whose resources are also integrated by the customer through the emergent category of network quality. Key constructs in B2B and B2C contexts are compared in Tables 4 and 5. We discuss the results with respect to each of our three objectives in turn.

The construction of customer experience quality

We found that-with the aid of repertory grid as a surfacing technique, at leastrespondents can articulate how they judge customer experience quality. As Table 3 shows and as we discuss in detail below, this construction includes such commonly identified categories of service quality as "Value For Time" (close to Parasuraman et al.'s (1988) timeliness), a "Caring Attitude" (close to the empathy dimension) and "Reliability." Experience quality goes beyond the notion of service quality, however, spanning Payne et al.'s (2008) delineation of the communication encounter (e.g., the "Communication" category), the service encounter (e.g., "Application of Knowledge," "Caring - Procedures and Processes") and the consumption encounter (e.g., "Social Impact," "Relationship with Other Customers"), which we incorporated in our definition of customer experience. These categories were not explicitly prompted for by the interviewer but rather emerged 
unprompted from the repertory grid process and its single question about the customer's experience with firms.

This suggests that customers do indeed assess their customer experience holistically, consistent with previous conjectures (Payne et al. 2008; Verhoef et al. 2009). For this experience assessment to meet the definition of quality, however, requires that customers also assess its excellence or superiority. We found that respondents could readily articulate the poles of their experience constructs and rate suppliers on each construct. It was also apparent from the transcript data that this rating had a valence (with the exception of the constructs within the experience context category which we discuss below); that is, respondents had a preferred pole, and would frequently spontaneously elaborate on why a "positive" rating on the construct was preferred. A B2B respondent, for example, explained why he preferred to have a designated contact point (construct \#4, Dedicated contact points, in Table 3): "Two of these [suppliers] have a focal point, i.e., a head that would make himself very open to whatever kind of contact stroke debate we need to have. I would have one hundred percent confidence that I could ring that person and something would happen. The opposite of that would be a lack of definition in the contact strategy. So I suppose the rules of engagement would be very blurred. As a result, responsiveness would be negatively impacted" (Respondent 38_B2B; see Table 1 for respondent profiles). Similarly, a B2C respondent explained how two companies' expensive services were preferred because they emphasized her status (\#101): "The fact that I use them shows that I can afford to ... It represents my standing-my economic standing, my personal aspirations. The first service organizations represent my personal status" (24_B2C).

These examples are typical of most constructs in which the positive pole is intuitively clear. In a few cases where the valence is not intuitively clear, respondents explained their view of which was the positive pole. For example, a higher degree of manufacturing self- 
sufficiency (\#58) was preferred by a hotel executive: “This is a supplier that delivers all sorts of products. The other suppliers not only deliver, but they also manufacture their own products. The first supplier - the distributor-is only the middle man. You take a chance; there is nothing you can actually go and check. It's only a distribution warehouse. But with the manufacturer, you can check the quality of the products-so, you know what you going to get. And we do check it beforehand" (67_B2B). Similarly, a consumer respondent justified his preference for a company that targeted customers more specifically than others $(\# 73)$ : "When dealing with this company, I feel good, because I feel the whole proposition seems to be aimed at people like me. It's up-market. It's the way they talk. Intelligent people. They target a specific segment where I put myself in. The image-the other company-well, I feel it's catering for the masses, which leaves me unsure to the extent that they really understand my needs" (18_B2C). This is consistent with attribution theory findings that ambiguous behaviors are disambiguated using contextual clues (Trope 1986), and that even the most value-neutral words have an evaluative dimension (Bargh 1992). Hence, the customer experience constructs consistently represent quality perceptions. We summarize this discussion in the following proposition.

P1: Customers construe customer experience quality and not just product and service quality.

Each of these spontaneous elaborations of the meaning of constructs can be read as relating the construct to higher-level or more "abstract" goals (Barsalou 1991; Peterman 1997). In some cases this causal link is more explicit, as for this e-commerce executive (\#60): "Two of the suppliers are very supportive and offer their resources to support projects. So, when they know what we are trying to achieve, they would offer time to help us to achieve our goals. For example, with one supplier we have a contact in place that we can use for so many working days a year. They could just leave it and provide that. And it would be fine. But actually, what they do is helping us sourcing our products and offering us advice on what 
would be suitable for us. The third supplier is more remote. They provide a service and that's it" (68_B2B). Similarly, a B2C respondent was clear on the "functional and/or hedonic outcome, purpose or objective that is directly served through product/service usage" (as we defined value-in-use) that he gained from a music festival (\#87): “This one provides a space for important conversations and experience in my life. This includes but is not limited to falling in love, having deep chats with old and new friends.... And on the other end of the scale, whether or not the experience was typically good is not-the experience is less important to my life" (18_B2C).

The absence of constructs with no valence, and the frequent presence of a hypothesized causal pathway between the experience construct and the customer's goals even without this attribution being prompted for, are consistent with our earlier observations from goal theory that as customers, we notice what has meaning for us as contributing to our goals (Puccinelli et al. 2009), and hence with our argument that we judge our customer experience quality by assessing its impact on value-in-use. We would expect, therefore, that:

P2: Value-in-use mediates between customer experience quality and relationship outcomes such as commitment, purchase, retention and word-of-mouth.

This builds on Zeithaml's (1988) argument for value mediating between service quality and relationship outcomes, and refines the experience frameworks of Grewal et al. (2009), Voss et al. (2008), Verhoef et al. (2009) and Payne et al. (2008). Further quantitative research is, however, required to provide empirical confirmation of this proposition.

A conceptual model of customer experience quality

In Figure 1, the customer experience quality categories of Table 3 are grouped according to Payne at al.'s (2008) distinction between the communication encounter, the service encounter and the usage encounter, with three exceptions. First, the "Outcomes" category represents evaluations of the perceptual and factual outcome of the experience. Second, respondents also 
reported ten constructs within the category of "Experience Context". Third, value-in-use acts as a mediator between customer experience quality and relationship outcomes, according to Proposition 2 above.

\section{Insert Figure 1 about here}

The communication encounter The communication encounter includes two categories.

"Communication" relates to clear, open, responsive, proactive and effective communication with the customer throughout the company and through the transactional customer journey, from initial contact (constructs \#39, Advertisement; \#40, Appropriateness of direct mail) through the purchase process (e.g., \#42, Enquiry responsiveness; \#45, Provision of information to inform choice) and after purchase (e.g. \#46, Updating customer on current position). In the construct Communication within supplier organization (\#41), the customer evaluates the offstage (Stuart and Tax 2004; Voss et al. 2008) processes by which supplier touchpoints share information with each other. This is consistent with Sousa and Voss's (2006) conceptualization of multichannel integration.

The second category within the communication encounter, "Relationship with Company," by contrast, concerns a relationship over time and over a series of transactions, and in particular the extent to which the firm genuinely values (e.g., \#77, Genuine desire to develop value for both parties) and appropriately maintains (e.g., \#81, Proactive relationship development) this relationship. While relationship quality and value have been much studied from the perspective of the firm (Bolton et al. 2008; Ryals 2005), the customer's perception of relationship quality has also received attention (De Canniere et al. 2009; De Wulf and Odekerken-Schroder 2003). This category confirms the importance of relationship quality, at least in some contexts—Regular repurchase product/service type (\#54) being one construct within the "Experience Context" category—and adds some depth to its construction. 
Valuing of the relationship involves acknowledgement of the benefits accruing to the firm (\#83, Valuing of custom) and hence the need to meet exchange norms through a willingness to invest in the relationship: "they won some minds and not a physical business, which means that they might win some more the next time around" (62_B2B). Construct \#77, Genuine desire to develop value for both parties, seems to go beyond the exchange norm of reciprocity to the appreciation of the endeavour of firm representatives to give value for its own sake: "They genuinely want to do the best solutions and want to help me...It's like having another member of the team ... it does not feel like having a supplier. It is like having a colleague or external partner" (3_B2B). This provides field-based support from both B2B and B2C settings for Aggarwal's (2004) experimental finding that consumer brand relationship expectations may have aspects not just of interpersonal exchange relationships, in which benefits are given to others to get something back, but also of communal relationships, in which benefits are given to show concern for others' needs.

Appropriate maintenance of the relationship includes behaviors that relate to all three of Gwinner et al.'s (1998) categories of customer perceived relational benefits-special treatment, social and confidence benefits-supporting the relevance of these beyond Gwinner et al.'s (1998) context of consumer services. Special treatment behaviors include price incentives for loyalty (\#103 and \#104 in "Value for Money" category) and proactive relationship development (\#81). The presence of a social relationship (\#80) aiding trust may be bolstered by consistency in service personnel (\#75) and a breadth of contact within the firm (\#74). Confidence is impacted through the presence or absence of trustworthy behavior (\#82): "they are using your contact within your organization to make contact with other people inside your organization, but not keeping you informed about it. So, they are looking for other work, but not respecting their relationship with you so that they let you know what they're doing. It comes as a surprise when you find out that they're talking to other people. 
And they used your name as an introduction. The other two suppliers don't do that. So, it's a very trusting relationship" (63_B2B). Aaker et al. (2004) find that such transgressions are forgiven less readily when the brand has presented itself as sincere rather than exciting, a further indication that relationship quality expectations are highly context specific.

The service encounter The service encounter includes a number of categories that are familiar from literature on product and service quality. "Variety/Choice," that the company provides and makes available an appropriate selection of products (constructs \#114 to \#119), is referred to as "Assortment" in retailing literature (Verhoef et al. 2009). "Value for Money" is defined as pricing of products and services that reflects benefits delivered and relationship status. While some studies view value for money as a holistic assessment of benefits relative to sacrifices (e.g., La et al. 2009; Sweeney and Soutar 2001) and hence as a consequence of such embedded-value measures as service quality (Zeithaml 1988), it is clear from the category's individual constructs (e.g. \#109, Price relative to market average; \#103, Availability of discounts) that it represents pricing attributes of the exchange rather than holistic sacrifices including those in the use process. Hence, value for money is best viewed as an embedded-value category parallel to, rather than consequent to, dimensions of product and service quality. This is consistent with the conception of Price within Verhoef et al.'s (2009) experience model.

Eight of the categories closely relate to SERVQUAL (Parasuraman et al. 1988) and its variants, as would be expected from the conception of customer experience quality as including but not being limited to quality perceptions of the service encounter. "Caring Attitude," "Caring - Procedures" and "Reliability" are close to the SERVQUAL dimensions Empathy, Assurance and Reliability respectively, while "Accessibility" is close to the Access category of Parasuraman et al.'s (1985) original qualitative study, and to several items from SERVQUAL. "Value for Time" relates to Responsiveness, but perhaps with more emphasis 
on the impact of the supplier's service on the customer's time (e.g. \#112, Efficient use of customer's time). "Atmosphere," or the extent to which the company enables a pleasant and relaxing environment, relates to Tangibles, though again perhaps with more explicit indication of the importance of the service attribute in the customer's goal hierarchy, in this case to hedonic utility during the service encounter (Sanchez-Fernandez et al. 2009). "Personalization"- dealing with the customers in a personal way and adapting the offer to meet their needs-builds on the two items of SERVQUAL that concern individualization and relates to much recent work on both personalized dialogue (Homburg et al. 2009; Ramani and Kumar 2008) and customization of the core product/service (Rust and Thompson 2006). "Application of Knowledge" is close to the Competence category within Parasuraman et al.'s (1985) original qualitative study.

The final category within the service encounter is "Network Quality"- the extent to which the company brings to bear appropriate competences from its internal and external networks. This category was the only one which emerged only amongst B2B respondents. Appropriate use of the firm's own suppliers for sourcing (\#60), for provision of advice directly to the customer (\#59) and for relationship development (\#57) can be perceived as beneficial—as equally can use of in-house resources such as manufacturing (\#58) and advice from subject experts (\#12, within the category "Application of Knowledge") where this provides benefits to the customer. While the absence of this category in the consumer context is consistent with the traditional view of the supply chain as an offstage process which is invisible to the customer (Stuart and Tax 2004), its presence among business respondents echoes the servicedominant logic view of both customers and suppliers as resource integrators (Vargo and Lusch 2008) and relates to calls for more work taking a network perspective to the cocreation of value (e.g. Cova and Salle 2008). Recent empirical work within this tradition includes Macdonald et al.'s (2009) case study data with a provider of industrial maintenance 
services. In this study, customers perceived that the provider's sourcing network "forced suppliers to work together" and gave the customer "clout," leading to products being obtained reliably, on time and at low cost, and reducing maintenance difficulties in the factory through supplier collaboration. Another echo of this category is McColl-Kennedy et al.'s (2009) exploration of the complex resource networks assembled by health patients: individuals look to a single supplier such as a primary care practitioner not just for direct delivery of service but also to facilitate the customer's construction of a wider resource network.

The usage encounter The usage encounter is represented by two closely related categories: "Relationship with Other Customers" (the role of other customers, including their identity and their involvement in value creation) and "Social Impact" (the impact of products/services on the customer's own image). The role of other customers in creating value has been explored within the retail setting (Verhoef et al. 2009), during service delivery within services contexts (Arnould and Price 1993; Diamond et al. 2009; Thakor et al. 2008) and during consumption processes through work on brand community (Schau et al. 2009; Schembri 2009; Schouten et al. 2007). Its presence as a category of customer experience quality suggests that customers evaluate the quality of the peer-to-peer encounter as part of their overall experience assessment. Suppliers are judged against this peer-to-peer encounter despite its falling outside their direct control, albeit often within their sphere of influence (Verhoef et al. 2009). The social impact of products and services also extends to noncustomers ("Social Impact"). While the socially constructed meaning of brands has been extensively researched (Pullman and Gross 2004; Ritchins 1994; Woodruff and Flint 2006), it is again noteworthy that this category is construed as part of customer experience quality.

Relationship outcomes, value-in-use and experience context

While we have conceived customer experience quality as leading to value-in-use and hence relationship outcomes, a few constructs nevertheless emerged which represent evaluations of 
the outcome of the experience ("Outcomes" category in Table 3). An emotional commitment (\#61, Affective commitment) can result from a perception that "they looked after me in the past" and hence that "I give something back" (4_B2C), consistent with social exchange theory (Cropanzano and Mitchell 2005). The experience may leave the customer "feeling good and enriched" (\#62)—another construct which, despite our characterisation of quality as primarily cognitive, is consistent with Baumeister et al.'s (2007) finding that emotions provide feedback stimulating learning and reappraisal, affect hence influencing cognition. Experiences also differ in their memorability (\#63, Impression impact). Some experiences are sufficiently memorable to result in word-of-mouth: a B2C respondent reported that when travelling by air, on some occasions "I would not be able to say which carrier [for transport] I have taken last week." On other occasions, though, the journey was sufficiently memorable that "I would use [the experience] as an interesting story to tell friends or relatives." This supports Gilmore and Pine's (2002) exhortation to construct memorable experiences. The final construct, Outcome of relationship (\#64), simply represented whether the relationship had resulted in the supplier being given the work - that is, a behavioral outcome of purchase. Overall, it can be presumed that the "Outcomes" category does not represent a saturated view of perceptual and behavioral outcomes. In Figure 1 we therefore focus on four perceptual and behavioral relationship outcomes present in much previous research: commitment (e.g., Briggs and Grisaffe 2010; Swinyard 1993; also construct \#61); initial and cross-buying purchase (e.g., Gentile et al. 2007; Voss et al. 2008; also \#64); retention (e.g., Pullman and Gross 2004; Voss et al. 2008); and word-of-mouth (e.g., Pullman and Gross 2004; Sweeney and Soutar 2001).

Similarly, the customers' diverse goals, purposes and objectives which constitute value-inuse were not intended to emerge from the data in the form of repertory grid constructsalthough we have observed that indications of value-in-use and its causal connection with 
experience quality constructs were spontaneously present in the respondents' talk. In Figure 1 we therefore include a delineation of value-in-use categories synthesized from value research (Chitturi et al. 2008; Holbrook 2006; La et al. 2009; Sanchez-Fernandez et al. 2008; Sweeney and Soutar 2001). We will return to the issue of how value-in-use might be elicited at a finergrained level in our suggestions for future research.

The final category is "Experience Context," defined as aspects of the industry, market or product category which may shape expectations of the experience. In addition to the ten constructs in this category, the comparison of key constructs in B2B and B2C contexts in Tables 4 and 5 provides a further lens for examining the role of context, which we will return to in detail later. Four themes predominate within this category. First, whether the product/service category is inherently hedonic (\#48) or otherwise emotive (\#47) has a clear relationship with whether hedonic value-in-use is sought. Second, involvement (\#53) or the transactional significance which leads to it (\#55) leads to a greater weight of service expectation, for example: "the service for that meant more to me because it was a big investment. The first two products were not big investments ... I didn't expect the customer service to be exceptional or anything” (70_B2C). Third, product/service complexity (\#52) can add to the importance of experience categories such as application of knowledge, personalization and communication: this is reflected in many of the differences between key constructs in $\mathrm{B} 2 \mathrm{~B}$ and $\mathrm{B} 2 \mathrm{C}$ contexts which we return to later. Fourth, some product/service categories in both $\mathrm{B} 2 \mathrm{~B}$ and $\mathrm{B} 2 \mathrm{C}$ contexts are perceived as inherently more relational, with regular repurchase the norm (\#54), raising the importance of relationship quality in these categories. While product/service categories vary in their relationality within both $\mathrm{B} 2 \mathrm{~B}$ and B2C contexts, this theme again emerges in the comparison between these contexts in Tables 4 and 5. It has been widely observed that value is contextual - that it is heavily dependent on the customer's context, including their situation (Holbrook 2006), the extent to which their 
goals are hedonic versus utilitarian (Chitturi et al. 2008), and their level of involvement (Puccinelli et al. 2009; Swinyard 1993). The presence of the "Experience Context" category in our data demonstrates that customer experience quality is similarly contextual.

Contrasting the conceptual model with previous experience frameworks

We conclude our discussion of Figure 1 with some reflections on its relationship with previous models of customer experience. Verhoef et al.'s (2009) model appears to share much with ours, though we have generalized beyond retailing contexts. A vital distinction, however, is that Verhoef et al. (2009), in common with Grewal et al. (2009), regard such elements as price, atmosphere and service as antecedents to the customer experience, whereas our emphasis on customer experience quality focuses on the perceived excellence or superiority of these categories, which are only relevant if they appear in the customer's construction. Because this construction relates to the value-in-use sought by the customer, there are hence some subtle variations: location, for example, is perceived through such constructs as geographical availability (\#6) and making an efficient use of the customer's time (\#112), an under-researched issue in the view of Grewal et al. (2009). This observation, when combined with the emphasis on context specificity which Figure 1 shares with both Verhoef et al.'s (2009) and Grewal's (2009) frameworks, carries the important practical implication that experience survey design needs to begin not by listing every touchpoint which the customer is behaviorally observed to come into contact with, but with qualitative exploration of how the customer's mental model of experience quality is exemplified in the specific context.

Our data confirm the view of Verhoef et al. (2009, p .32) amongst others, though, that experience is co-created: "created not only by those elements which the retailer can control ... but also by those elements that are outside of the retailer's control (e.g. influence of others, purpose of shopping)." Payne et al. (2008) usefully distinguish supplier processes, customer 
processes and encounter processes which may contribute to the co-creation of customer experience and mutual value. We confirm empirically that each of these is present in the customer's conception of customer experience quality, hence extending Verhoef's (2009) model which focuses on the communication and service encounter. Hence we propose:

P3: Customer experience quality includes an assessment not just of communication and service quality but also of usage quality.

The notion of customers as resource integrators (Vargo and Lusch 2008) widens the concept of co-creation to the wider network within which both customers and suppliers reside. This is apparent in our data not just in the role of other customers but also in that of other suppliers ("Network Quality" category), as the actors negotiate and evolve their respective roles. For some B2B customers, at least, other suppliers are not offstage, as conceived by Grewal et al. (2009) in the B2C retailing context, but onstage: the customer's experience with the supplier's network is construed as part of customer experience quality. Hence we propose:

P4: Customer experience quality includes an assessment of the quality of the customer's encounter with other customers and other suppliers whose resources are integrated with those of the supplier in order to achieve value-in-use.

This proposition represents a refinement of the popular view of experience as excellence across all firm touchpoints. Rather, it brings to mind the conclusions from the ethnographic work of Diamond et al. (2009, p. 131) on American Girl: "If brands represent symphonies of meaning, managers must be viewed as orchestrators and conductors, as well as composers, whose role is to coordinate and synchronize as well as create."

Comparing business and consumer contexts

We have seen that customer experience quality is contextual. As a first step towards examination of how customer experience quality varies by context, we will contrast the key constructs (according to Goffin et al.'s 2006 methodology) found within B2B and B2C contexts, as listed in Table 4 and Table 5. 
The key $\mathrm{B} 2 \mathrm{~B}$ constructs are striking in their focus on the application of knowledge to understand and contribute to the customer's specific objectives. An excellent experience is one where supplier personnel implicitly possess a deep understanding of customer needs (\#13): "When you explain a project, you don't have to explain the context ... and therefore, their offer is more in tune with your needs" (63_B2B). Front-line staff then actively seek to elicit the customer's specific objectives (\#20): “They try to find out what I would like to achieve and what my objectives are. And even if I say 'I would like to do X', they probably say 'I understand you want to do $\mathrm{X}$, but just explain to me a little bit why you want to do $\mathrm{X}$, so that I understand your motivations better"' (3_B2B). Knowledge is then applied (\#14) to modify the offering appropriately (\#70, Flexibility): “They add value by their experience and can recommend other or even better ways. They use their experience of the industry and add value; they give me something that I haven't got by their particular knowledge” (3_B2B). This flexibility is needed after the sale is made as well as before: "When working on site ... we sometimes realize too late that something is missing. Then you need a supplier who is flexible to help us. This might mean that we have to change the contract slightly in terms of deadlines, content and so on. Many suppliers are inflexible in this regard" (65_B2B). The company will then not just fulfill its promises (\#96) but also actively check that the customer is thereby meeting their objectives (\#26). The richness of this dialog makes personal contact methods attractive (\#69).

These data are notably supportive of Vargo and Lusch's $(2004,2008)$ argument that the application of knowledge and skills is the fundamental basis of exchange (their first foundational premise (FP1)) and hence the fundamental source of competitive advantage (FP4). Whether or not this knowledge is embedded in goods (FP3), it is applied through service to enable the customer to co-create value-in-use (FP6). As this value-in-use is uniquely determined by the beneficiary (FP10), it would seem plausible that the value 
proposition offered by the provider will often need tailoring to this unique set of goals, purposes or objectives-whether or not goods are customized. Tuli et al. (2007) make a closely related argument that customers buy relational processes of iterative knowledge application to provide solutions, rather than product bundles.

If the application of knowledge and skills is the fundamental basis of exchange, though, Vargo and Lusch (2004) also make the point (FP2) that indirect exchange, in particular via goods, can mask this basis of exchange. The less immediately evident role of knowledge in Table 5, which is broadly consistent with SERVQUAL and its variants, may be because in a B2C context, company offerings are more likely to be standardized (Anderson et al. 1997; Fisk et al. 1993), with knowledge embedded into their design. The desirability of a degree of personalization in order to co-create idiosyncratic value-in-use for an individual consumer is nonetheless evident in several of these constructs, notably recognizing the customer (\#67), personalizing service delivery (\#71), and taking ownership of the customer's problems (\#25). In these and other constructs such as Value for time (\#113), we were struck by how the attitude with which service is provided-explicit in the constructs within the "Caring Attitude" category such as Helpfulness (\#23), but implicit elsewhere-seems to be as important as the immediate outcome: "In this shop there are busy times and less busy times, but their tills are always manned at busy times.... This doesn't mean that the waiting time is short, but they do what is possible.... You cannot expect them to build new tills, can you?" (\#113, 72_B2C). The importance of attitude seems to be not only as a means to the customer's self-oriented end (Holbrook 2006) such as utilitarian value but also to provide other-oriented value through status or esteem ("I felt valued when dealing with this company," 5_B2C). This is reminiscent of the role of "VIP emotion" in Pullman and Gross's (2004) study of hospitality tent experience at a travelling circus, and of Ritchins's (1994) value category of identity and self-expression. Based on case data, Macdonald et al. (2009) 
suggest that attitude can further act as a cue (Gentile et al. 2007) for future value, hence addressing a preventative goal (Chitturi et al. 2008) of lowering future risk.

This comparison of key constructs in B2B and B2C contexts demonstrates, then, that there are some differences in how suppliers apply their knowledge and skills to co-create value-inuse, and hence some differences in the construction of customer experience quality. We note that these differences are only present on average, however. This is apparent from the large proportion of constructs, and even larger proportion of categories, which were found amongst both B2B and B2C respondents (see Table 3). Coviello et al. (2002) found that while B2B contexts tend to be more relational and B2C contexts more transactional, this was far from universally the case; and Fisk et al. (1993) and Anderson et al. (1997) argue that B2B contexts tend to involve more customization but again far from universally. Similarly, we would expect the most important customer experience quality constructs to vary according to specific context, including the product/service category. With this proviso, we can interpret the differences found in key constructs across B2B and B2C contexts as follows.

In typical $\mathrm{B} 2 \mathrm{C}$ contexts, the product/service design process appears to be primarily offstage. Knowledge is embedded in this design: knowledge of "objectives, purposes or outcomes" commonly sought by customers is combined with technical knowledge of how these value-in-use aspirations can be met. Onstage service personnel are left with the comparatively straightforward task of helpfully listening to the openly declared needs of the customer, matching the value-in-use a customer seeks with the appropriate product/service with relatively little personalization, and ensuring the competent and efficient delivery of this product/service. Customers do not expect the firm to monitor the value they gain in use, but do hold the firm accountable for the delivery of the promised embedded value through product and service quality. 
In typical B2B contexts, by contrast, knowledge is required to elicit the value-in-use sought by the customer, and to configure an appropriate solution in collaboration with the client, potentially involving extensive customization. More of the design process is hence onstage. High customer experience quality arises not just from delivering the promised embedded value, but also from monitoring the customer's achievement of value-in-use through their own use processes.

Deeper customer insight, then, is required in a typical B2B context when dealing with an individual customer. In both contexts, high experience quality results from an endeavour to satisfy customer needs and hence as exhibiting market orientation (Kohli and Jaworski 1990; Narver and Slater 1990), but marketing orientation works somewhat differently in the two contexts. A service-dominant perspective helps to distinguish between needs at the embedded-value level, as met by product/service attributes, and needs at the level of the value-in-use sought by the customer-deeper needs, in the language of the positive pole of the construct Implicit understanding of customer needs (\#13): "What customer experience needs to dwell on is the actual output. So, how the output relates to the brief to some degree. So, I suppose, getting under the skin a little bit more, it's the interpretation of the brief" (38_B2B); "These two are similar companies-similar experiences-because it feels like they are selling a commodity ... they don't try to understand your needs. The third supplier is trying to differentiate themselves. They sell software and they are very keen on trying to understand your business more. So, they are able to tailor their offer better" (61_B2B).

We summarize this discussion in the following proposition:

P5: In B2B contexts, customer experience quality is enhanced by supplier practices which focus on understanding, co-creating and monitoring the achievement of value-in-use. 


\section{Implications for practitioners}

Customer experience remains a resonant concept in practitioner discourse, but also an illdefined one. One danger is that experience simply becomes a rebranding of service: "Effective management of the customer experience across all touch points ... is the key to building customer commitment, retention, and sustained financial success. Only the companies that deliver the right experience to customers will succeed in the global marketplace" (Seddon and Sant 2007). By contrast, as we have seen, customer experience quality is perceptual and intimately related to the customer's goals, to which some touchpoints may not be relevant; and equally, other categories of customer experience quality do not involve touchpoints at all.

The preponderance in practitioner literature of experience examples from certain largely hedonic contexts such as leisure has the benefit of demonstrating that experience is cocreated with the firm rather than delivered by it. But a second danger is a consequent misunderstanding that the ideal customer experience is whatever leads to positive emotions, particularly of surprise or delight (Shaw 2002). Rather, the goals we seek are as rich as our imaginations, and are highly context-specific. And so, therefore, is the customer experience quality by which we judge the firm's direct and indirect contribution to these goals.

Managers thus need to extend their view beyond the factory gate or service touchpoint to both understand and, where appropriate, reshape co-creation processes during which the nearest service channel may be nowhere in sight. We contribute to the customer insight challenge that this creates not so much in the specifics of our customer experience quality model, but rather through suggesting a method by which customer experience quality can be elicited in the firm's context. Practitioners may wish to consider the repertory grid technique for the qualitative stage of such customer insight work - a technique which, while not widely known amongst market research practitioners, is not difficult to learn. Notable areas in which 
customer experience quality may be found to extend beyond service quality, dependent on the context, are peer-to-peer quality, network quality and relationship quality, as well as the customer's own usage processes.

Practitioners in firms providing a high degree of personalization or customization, as is more common in $\mathrm{B} 2 \mathrm{~B}$ contexts though also the case in some $\mathrm{B} 2 \mathrm{C}$ contexts, may also wish to consider the extent to which the culture and processes of front-line staff provide sufficiently "deep insight" into the explicit or implicit outcomes, purposes or objectives sought by the customer, and equally, whether quality is measured purely by the delivery of the promised embedded value, or instead by the customer's achievement of these outcomes, purposes or objectives.

\section{Suggestions for future research}

One natural next step for research on customer experience quality is to develop scales for the concept, as both scholarly research and practice might benefit from tools that could be used in survey designs. While Verhoef et al. (2009) called for the development of a customer experience scale, we have argued that the importance of context in our data might suggest some significant variation in such a scale by context. As a minimum, the relative importance of the experience categories in the model of Figure 1 might be found to vary according to context. Ideally, work in specific product/service categories might benefit from some additional context-specific qualitative exploration using a method such as repertory grid, to check the salience of categories and the constructs within them, and to check for any contextspecific additional constructs.

Such work towards quantification might be expected to shed light in particular on the dimensions of quality in co-creation processes, such as peer-to-peer quality, which has primarily been explored qualitatively to date. It seems surprising that usage process qualitythe excellence or superiority of the customer's own usage processes—did not emerge more 
directly in our data; perhaps, while the presence of other customers is regarded as at least in part the responsibility of the supplier and hence is construed as part of "the experience you have with" the supplier, the customer's own processes may require more specific prompting. Macdonald et al.'s (2009) case data would suggest that with this industrial maintenance context at least, customers can indeed articulate their own excellence or lack of it in their usage processes in contributing to their own goals. Further research is needed to establish the generalizability of usage process quality.

The emphasis, particularly in our B2B data, on uncovering and satisfying the value-in-use sought by the customer suggests two lines of further enquiry. The first is to seek to confirm our Proposition 5 through quantitative work along the lines of market orientation studies. The second is to explore whether value-in-use, like customer experience quality, can be directly elicited and perceptually measured. In the language of service-dominant logic, previous measures of value (La et al. 2009; Sanchez-Fernandez et al. 2009; Sweeney and Soutar 2001) mix up and, perhaps, are in some cases in danger of confusing embedded-value and value-inuse components. There may be merits in separating out the customer's achievement of their goals, purposes and objectives from their assessment of the company's contribution towards these goals. As with customer experience quality, we would however expect such value-inuse measures to be highly context-specific. Such measures would enable the exploration of such propositions as Proposition 2, that value-in-use mediates the relationship between customer experience quality and customer relationship outcomes. This proposition, if supported empirically, would provide a possible explanation for the empirical difficulties found in the expectancy confirmation model of service quality: expectations of service, as of the wider customer experience, are formed not in themselves but in relation to the goals sought. In particular, some customers have a goal hierarchy in which, while the abstract goals are defined in advance, the concrete goals such as service quality expectations are not. 
Choice of the methods by which such propositions are explored will, however, be nontrivial. Both experience and value-in-use are processual, suggesting that explicitly longitudinal designs might be beneficial (Brakus et al. 2009; Sengupta et al. 1997). Furthermore, the role of networks of actors in the co-creation of value might benefit from designs which explore value creation from an explicitly multi-stakeholder network perspective (Vargo and Lusch 2008; Woodruff and Flint 2006).

\section{Concluding remarks}

Customer experience continues to be much discussed by practitioners, but the empirical research base is comparatively slight (Verhoef et al. 2009). We have explored one primarily cognitive aspect of experience with implications for firms' customer insight processes: customer experience quality. We found that-with the help of repertory grid as a surfacing technique-customers can indeed articulate the constructs by which they assess customer experience quality, if not asked an excessively narrow question about service quality or "the value you get from us." We also found that a focus on customer experience quality opens the door to understanding more fully how customers achieve their goals, and hence, perhaps, widens the firm's creative options for how it might better contribute to value-in-use cocreation. Research directions this suggests include the more explicit elicitation of these goals themselves and the extension of quality research beyond the firm's processes into the customer's usage processes.

Understanding the customer's perception of experience emphasises how easy it is for academics and practitioners alike to fall into focusing exclusively on the boundary between the firm and the customer. Understanding the customer's space involves entering their world, which is processual, relational, embedded in a rich network of peers and complementary suppliers, and largely outside the firm's direct control. Thankfully this does not make 
customer experience unresearchable or irredeemably amorphous; we just have to ask the right questions in a suitable fashion. 
TABLES

Table 1:

Sample

\begin{tabular}{|c|c|c|c|c|}
\hline \multicolumn{5}{|c|}{ Business-to-consumer $(B 2 C)$} \\
\hline & \multicolumn{4}{|l|}{ Gender: } \\
\hline Age: & \multicolumn{2}{|l|}{ Female } & \multicolumn{2}{|c|}{ Male } \\
\hline $16-34$ & & \\
\hline & \multicolumn{2}{|c|}{$\begin{array}{l}\text { (9_B2C; 15_B2C; 27_B2C; 53_B2C; } \\
\text { 70_B2C) }\end{array}$} & \multicolumn{2}{|c|}{ (1_B2C; 16_B2C; 71_B2C) } \\
\hline $35-49$ & \multirow{2}{*}{\multicolumn{2}{|c|}{$\begin{array}{l}5 \\
\left(24 \_B 2 C ; 54 \_B 2 C ; 57 \_B 2 C ; 59 \_B 2 C ;\right. \\
\left.73 \_B 2 C\right)\end{array}$}} & \multirow{2}{*}{\multicolumn{2}{|c|}{$\begin{array}{l}4 \\
\left(4 \_B 2 C ; 5 \text { _B2C; } 18 \_B 2 C ; 56 \_B 2 C\right)\end{array}$}} \\
\hline & & & & \\
\hline $50+$ & \multicolumn{2}{|c|}{$\begin{array}{l}3 \\
\left(6 \_B 2 C ; 48 \_B 2 C ; 72 \_B 2 C\right)\end{array}$} & \multicolumn{2}{|l|}{0} \\
\hline \multicolumn{5}{|c|}{ Business-to-business $(B 2 B)$} \\
\hline & \multicolumn{4}{|l|}{ Function: } \\
\hline Industry sector: & Marketing & \multicolumn{2}{|l|}{ Purchasing } & Operations \\
\hline Products & $\begin{array}{l}7 \\
\text { (2_B2B; 3_B2B; 31_B2B; } \\
\text { 35_B2B; 65_B2B; 68_B2B; } \\
\text { 69_B2B) }\end{array}$ & \multicolumn{2}{|l|}{1} & 0 \\
\hline Services & $\left(38 \_B 2 B ; 52 \_B 2 B\right)$ & \multicolumn{2}{|c|}{$\begin{array}{l}3 \\
\left(60 \_B 2 B ; 63 \_B 2 B ;\right. \\
\left.64 \_B 2 B\right)\end{array}$} & $\begin{array}{l}7 \\
\text { (49_B2B; 50_B2B; 51_B2B; } \\
\text { 55_B2B; 61_B2B; 62_B2B; } \\
\text { 67_B2B) }\end{array}$ \\
\hline
\end{tabular}

Each cell contains the number of respondents, followed by an identifier for each respondent which is used in the text to show the source of quotations. 
Table 2:

Example repertory grid (B2B respondent)

\begin{tabular}{|c|c|c|c|c|c|c|c|c|c|c|c|}
\hline \multirow[b]{2}{*}{$\#$} & \multirow{2}{*}{$\begin{array}{c}\text { Construct Pole } \\
\text { (1) }\end{array}$} & \multicolumn{9}{|c|}{ SUPPLIERS / “COMPANIES YOU DEAL WITH” } & \multirow{2}{*}{$\begin{array}{c}\text { Contrast Pole } \\
\text { (5) }\end{array}$} \\
\hline & & $\begin{array}{c}\text { Supplier } \\
1\end{array}$ & $\begin{array}{c}\text { Supplier } \\
2 \\
\end{array}$ & $\begin{array}{c}\text { Supplier } \\
\mathbf{3} \\
\end{array}$ & $\begin{array}{c}\text { Supplier } \\
\mathbf{4} \\
\end{array}$ & $\begin{array}{c}\text { Supplier } \\
5\end{array}$ & $\begin{array}{c}\text { Supplier } \\
6\end{array}$ & $\begin{array}{c}\text { Supplier } \\
7\end{array}$ & $\begin{array}{c}\text { Supplier } \\
\mathbf{8}\end{array}$ & $\begin{array}{c}\text { Supplier } \\
9\end{array}$ & \\
\hline 1. & Clearly defined process & 1 & 5 & 1 & 4 & 3 & 3 & 1 & 1 & 1 & Not clearly defined process \\
\hline 2. & Good value for money & 2 & 5 & 2 & 5 & 2 & 1 & 2 & 2 & 5 & Charge extra \\
\hline 3. & High level of aftercare & 5 & 2 & 2 & 2 & 3 & 1 & 1 & 4 & 5 & No aftercare \\
\hline 4. & $\begin{array}{l}\text { Supplier does } \\
\text { documentation }\end{array}$ & 3 & 3 & 1 & 3 & 2 & 1 & 3 & 5 & 5 & Customer has to record it \\
\hline 5. & $\begin{array}{l}\text { Checking mutual } \\
\text { understanding }\end{array}$ & 2 & 4 & 1 & 5 & 2 & 1 & 2 & 5 & 5 & $\begin{array}{l}\text { Unconcerned with } \\
\text { understanding }\end{array}$ \\
\hline 6. & Complex product & 5 & 3 & 2 & 1 & 2 & 2 & 1 & 5 & 2 & Simple product \\
\hline 7. & Don't try to sell more & 1 & 1 & 2 & 5 & 2 & 1 & 2 & 1 & 5 & Hassle me \\
\hline & $\begin{array}{l}\text { Great variety of } \\
\text { providers }\end{array}$ & 2 & 1 & 3 & 5 & 3 & 1 & 4 & 1 & 5 & Monopoly \\
\hline 9. & Partner & 2 & 4 & 2 & 5 & 1 & 2 & 2 & 2 & 5 & Enemy \\
\hline 10. & Open dialogue & 2 & 5 & 2 & 5 & 2 & 1 & 1 & 2 & 5 & Diplomatic \\
\hline 11. & Adds value & 1 & 5 & 1 & 5 & 2 & 1 & 1 & 2 & 5 & Can't do the job \\
\hline 12. & High customization & 2 & 5 & 2 & 4 & 2 & 1 & 1 & 2 & 5 & Low customization \\
\hline & $\begin{array}{l}\text { Find out customer } \\
\text { objectives }\end{array}$ & 1 & 1 & 1 & 2 & 2 & 1 & 1 & 1 & 5 & Don't find out \\
\hline 14. & Fulfill promise & 1 & 2 & 5 & 4 & 2 & 1 & 2 & 2 & 4 & Break promise \\
\hline
\end{tabular}

Each row (numbered 1 to 14 in this example) represents a construct by which the respondent assesses customer experience quality.

Each of 9 suppliers named by the customer is rated from 1 to 5 on each construct, where 1 represents the "construct pole" (e.g., "Clearly defined process") and 5 represents the :contrast pole" (e.g., "Not clearly defined process"). 
Table 3:

Customer experience quality categories

\begin{tabular}{|c|c|c|c|c|}
\hline Category & $\#$ & Construct Label & $B 2 B$ & $B 2 C$ \\
\hline $\begin{array}{l}\text { Accessibility: Ease of finding and } \\
\text { accessing people, premises, transactions } \\
\text { and/or information whenever needed }\end{array}$ & $\begin{array}{l}1 . \\
2 . \\
3 . \\
4 . \\
5 . \\
6 . \\
7 . \\
8 .\end{array}$ & $\begin{array}{l}\text { Accessibility of information } \\
\text { Accessibility of person/facility } \\
\text { Convenient hours of operation } \\
\text { Dedicated contact points } \\
\text { Ease of order placement } \\
\text { Geographical availability } \\
\text { Geographical distance } \\
\text { Navigation }\end{array}$ & $\begin{array}{l}\sqrt{ } \\
\sqrt{ } \\
\sqrt{ } \\
\sqrt{ }\end{array}$ & $\begin{array}{l}\sqrt{ } \\
\sqrt{ } \\
\sqrt{ } \\
\sqrt{ }\end{array}$ \\
\hline $\begin{array}{l}\text { Application of Knowledge: Staff possess } \\
\text { and proactively apply the knowledge and } \\
\text { expertise necessary to create value for the } \\
\text { customer }\end{array}$ & $\begin{array}{l}9 . \\
10 . \\
11 . \\
12 . \\
13 . \\
14 . \\
15 .\end{array}$ & $\begin{array}{l}\text { Ability to create value } \\
\text { Application of up-to-date technological knowledge } \\
\text { Competence } \\
\text { Contact with subject experts } \\
\text { Implicit understanding of customer needs } \\
\text { Knowledge } \\
\text { Proactive sharing of ideas }\end{array}$ & $\begin{array}{l}\sqrt{ } \\
\sqrt{ } \\
\sqrt{ } \\
\sqrt{ } \\
\sqrt{ }\end{array}$ & $\begin{array}{l}\sqrt{ } \\
\sqrt{ }\end{array}$ \\
\hline $\begin{array}{l}\text { Atmosphere: Company enables a pleasant } \\
\text { and relaxing physical environment }\end{array}$ & 16. & Atmosphere & $\sqrt{ }$ & $\sqrt{ }$ \\
\hline $\begin{array}{l}\text { Caring - Attitude: Staff demonstrate a } \\
\text { genuine interest and care towards the } \\
\text { customer }\end{array}$ & $\begin{array}{l}17 . \\
18 . \\
19 . \\
20 . \\
21 . \\
22 . \\
23 . \\
24 . \\
25 . \\
26 . \\
27 . \\
28 .\end{array}$ & $\begin{array}{l}\text { Absence of pushiness } \\
\text { Attitude } \\
\text { Authenticity } \\
\text { Concern to elicit customer's objectives } \\
\text { Customer care } \\
\text { Friendliness } \\
\text { Helpfulness } \\
\text { Honesty } \\
\text { Interest in problem solving } \\
\text { Proactivity in checking that everything is OK } \\
\text { Professionalism } \\
\text { Taking responsibility }\end{array}$ & $\sqrt{ }$ & $\begin{array}{l}\sqrt{ } \\
\sqrt{ } \\
\sqrt{ } \\
\sqrt{ } \\
\sqrt{ } \\
\sqrt{ } \\
\sqrt{ } \\
\sqrt{ } \\
\sqrt{ } \\
\sqrt{ } \\
\sqrt{ }\end{array}$ \\
\hline $\begin{array}{l}\text { Caring - Procedures and Processes: } \\
\text { Processes to understand and address } \\
\text { customer needs, empower staff to respond } \\
\text { to problems, and track effectiveness }\end{array}$ & $\begin{array}{l}29 . \\
30 . \\
31 . \\
32 . \\
33 . \\
34 . \\
35 . \\
36 . \\
37 . \\
38 .\end{array}$ & $\begin{array}{l}\text { Aftercare } \\
\text { Clarity of sales process } \\
\text { Feedback } \\
\text { Performance evaluation } \\
\text { Provision of appropriate documentation } \\
\text { Safety } \\
\text { Service recovery / complaint handling } \\
\text { Staff empowerment } \\
\text { Staffing levels } \\
\text { Validation of mutual understanding }\end{array}$ & $\begin{array}{l}\sqrt{ } \\
\sqrt{ } \\
\sqrt{ } \\
\sqrt{ } \\
\sqrt{ }\end{array}$ & $\begin{array}{l}\sqrt{ } \\
\sqrt{ } \\
\sqrt{ } \\
\sqrt{ } \\
\sqrt{ }\end{array}$ \\
\hline $\begin{array}{l}\text { Communication: Clear, open, responsive, } \\
\text { proactive and effective communication } \\
\text { with customer throughout the company }\end{array}$ & $\begin{array}{l}39 . \\
40 . \\
41 . \\
42 . \\
43 . \\
44 . \\
45 . \\
46 .\end{array}$ & $\begin{array}{l}\text { Advertisement } \\
\text { Appropriateness of direct mail } \\
\text { Communication within supplier organization } \\
\text { Enquiry responsiveness } \\
\text { Explanation } \\
\text { Openness } \\
\text { Provision of information to inform choice } \\
\text { Updating customer on current position }\end{array}$ & $\begin{array}{l}\sqrt{ } \\
\sqrt{ } \\
\sqrt{ } \\
\sqrt{ } \\
\sqrt{ } \\
\sqrt{ }\end{array}$ & $\begin{array}{l}\sqrt{ } \\
\sqrt{ } \\
\sqrt{ } \\
\sqrt{ } \\
\sqrt{ } \\
\sqrt{ }\end{array}$ \\
\hline $\begin{array}{l}\text { Experience Context: Aspects of the } \\
\text { industry, market or product category, which } \\
\text { may shape expectations of experience. } \\
\text { Excludes aspects of the specific supplier } \\
\text { (its geographical location, exclusivity etc.) }\end{array}$ & $\begin{array}{l}47 . \\
48 . \\
49 . \\
50 . \\
51 . \\
52 . \\
53 . \\
\\
54 . \\
55 . \\
56 .\end{array}$ & $\begin{array}{l}\text { Emotive context } \\
\text { Hedonic product / service type } \\
\text { Importance of timeliness } \\
\text { Market competitiveness } \\
\text { Organizational size } \\
\text { Product complexity } \\
\text { Product/service type with high customer involvement in } \\
\text { service process } \\
\text { Regular repurchase product/service type } \\
\text { Significance of transaction } \\
\text { Supplier company status }\end{array}$ & $\begin{array}{l}\sqrt{ } \\
\sqrt{ } \\
\sqrt{ }\end{array}$ & $\begin{array}{l}\sqrt{ } \\
\sqrt{ } \\
\sqrt{ } \\
\sqrt{ } \\
\sqrt{ } \\
\sqrt{ }\end{array}$ \\
\hline $\begin{array}{l}\text { Networks: Company brings to bear } \\
\text { competences from its internal and external } \\
\text { network }\end{array}$ & $\begin{array}{l}57 . \\
58 .\end{array}$ & $\begin{array}{l}\text { Appropriate use of third parties for relationship } \\
\text { development } \\
\text { Degree of manufacturing self-sufficiency }\end{array}$ & $\sqrt{ }$ & \\
\hline
\end{tabular}




\begin{tabular}{|c|c|c|c|c|}
\hline & $\begin{array}{l}59 . \\
60 .\end{array}$ & $\begin{array}{l}\text { Network of specialists for advice } \\
\text { Sourcing network }\end{array}$ & $\begin{array}{l}\sqrt{ } \\
\sqrt{ }\end{array}$ & \\
\hline $\begin{array}{l}\text { Outcomes: Evaluations of the perceptual } \\
\text { and factual outcome of the experience }\end{array}$ & $\begin{array}{l}61 . \\
62 . \\
63 . \\
64 .\end{array}$ & $\begin{array}{l}\text { Affective commitment } \\
\text { Feel good factor } \\
\text { Impression impact } \\
\text { Outcome of relationship }\end{array}$ & $\sqrt{ }$ & $\begin{array}{l}\sqrt{ } \\
\sqrt{ } \\
\sqrt{ }\end{array}$ \\
\hline $\begin{array}{l}\text { Personalization: Dealing with customers in } \\
\text { a personal way and adapting the offer to } \\
\text { meet their needs }\end{array}$ & $\begin{array}{l}65 . \\
66 . \\
67 . \\
68 . \\
69 . \\
70 . \\
71 . \\
72 . \\
73 .\end{array}$ & $\begin{array}{l}\text { Bespoke dialogue } \\
\text { Customer need focus } \\
\text { Customer recognition } \\
\text { Customization } \\
\text { Extent of personal contact } \\
\text { Flexibility } \\
\text { Personalization } \\
\text { Proactivity in addressing customer's needs } \\
\text { Segmentation approach }\end{array}$ & $\begin{array}{l}\sqrt{ } \\
\sqrt{ } \\
\sqrt{ } \\
\sqrt{ } \\
\sqrt{ } \\
\sqrt{ }\end{array}$ & $\begin{array}{l}\sqrt{ } \\
\sqrt{ } \\
\sqrt{ } \\
\sqrt{ } \\
\sqrt{ } \\
\sqrt{ }\end{array}$ \\
\hline $\begin{array}{l}\text { Relationship with Company: Company } \\
\text { genuinely values and appropriately } \\
\text { maintains relationship with customer over } \\
\text { time and over a series of transactions }\end{array}$ & $\begin{array}{l}74 . \\
75 . \\
76 . \\
77 . \\
78 . \\
79 . \\
80 . \\
81 . \\
82 . \\
83 . \\
84 .\end{array}$ & $\begin{array}{l}\text { Breadth of contact } \\
\text { Consistency of service personnel } \\
\text { Ease of establishing relationship } \\
\text { Genuine desire to develop value for both parties } \\
\text { Interest in relationship maintenance } \\
\text { Number of people } \\
\text { Presence of social relationship } \\
\text { Proactive relationship development } \\
\text { Trustworthy behavior in relationship } \\
\text { Valuing of custom } \\
\text { Valuing of relationship }\end{array}$ & $\begin{array}{l}\sqrt{ } \\
\sqrt{ } \\
\sqrt{ } \\
\sqrt{ } \\
\sqrt{ } \\
\sqrt{ } \\
\sqrt{ }\end{array}$ & $\begin{array}{l}\sqrt{ } \\
\sqrt{ } \\
\sqrt{ }\end{array}$ \\
\hline $\begin{array}{l}\text { Relationship with Other Customers: The } \\
\text { role of other customers including their } \\
\text { identity and their involvement in value } \\
\text { creation }\end{array}$ & $\begin{array}{l}85 . \\
86 . \\
87 .\end{array}$ & $\begin{array}{l}\text { Exclusive } \\
\text { Impact of other customers } \\
\text { Providing space for customer-to-customer relationship } \\
\text { development }\end{array}$ & & $\begin{array}{l}\sqrt{ } \\
\sqrt{ } \\
\sqrt{ }\end{array}$ \\
\hline $\begin{array}{l}\text { Reliability: Company is dependable and } \\
\text { consistent regardless of personal attitude of } \\
\text { staff }\end{array}$ & $\begin{array}{l}88 . \\
89 . \\
90 . \\
91 . \\
92 . \\
93 . \\
94 . \\
95 . \\
96 . \\
97 . \\
98 . \\
99 .\end{array}$ & $\begin{array}{l}\text { Ability to check quality } \\
\text { Accurate invoicing } \\
\text { Acting as agreed } \\
\text { Consistency of experience over time } \\
\text { Delivery timeliness } \\
\text { Impression of reliability } \\
\text { Low incidence of problems } \\
\text { Product / Service quality } \\
\text { Promise fulfillment } \\
\text { Reliability of sales process } \\
\text { Timeliness of response } \\
\text { Track record }\end{array}$ & $\begin{array}{l}\sqrt{ } \\
\sqrt{ } \\
\sqrt{ } \\
\sqrt{ } \\
\sqrt{ } \\
\sqrt{ }\end{array}$ & $\begin{array}{l}\sqrt{ } \\
\sqrt{ } \\
\sqrt{ }\end{array}$ \\
\hline $\begin{array}{l}\text { Social Impact: The impact of products / } \\
\text { services on the customer's own image }\end{array}$ & $\begin{array}{l}100 \\
101 \\
102\end{array}$ & $\begin{array}{l}\text { Fashionable products / services } \\
\text { Impact on status } \\
\text { Premium brand }\end{array}$ & & $\begin{array}{l}\sqrt{ } \\
\sqrt{ } \\
\sqrt{ }\end{array}$ \\
\hline $\begin{array}{l}\text { Value for Money: Pricing of products and } \\
\text { services that reflects benefits delivered and } \\
\text { relationship status }\end{array}$ & $\begin{array}{l}103 \\
104 \\
105 \\
106 \\
107 \\
108 \\
109 \\
110\end{array}$ & $\begin{array}{l}\text { Availability of discounts } \\
\text { Availability of loyalty incentives } \\
\text { Delivery of value in excess of contract } \\
\text { Exceeding expectations without charge } \\
\text { Free contact with company } \\
\text { Negotiability of pricing } \\
\text { Price relative to market average } \\
\text { Value for money }\end{array}$ & $\begin{array}{l}\sqrt{ } \\
\sqrt{ } \\
\sqrt{ }\end{array}$ & $\begin{array}{l}\sqrt{ } \\
\sqrt{ } \\
\sqrt{ } \\
\sqrt{ } \\
\sqrt{ }\end{array}$ \\
\hline $\begin{array}{l}\text { Value for Time: Company values and } \\
\text { makes efficient use of customer's time } \\
\text { throughout customer journey }\end{array}$ & $\begin{array}{l}111 \\
112 \\
113\end{array}$ & $\begin{array}{l}\text { Ability to work independently } \\
\text { Efficient use of customer's time } \\
\text { Value for time }\end{array}$ & $\sqrt{ }$ & $\begin{array}{l}\sqrt{ } \\
\sqrt{ }\end{array}$ \\
\hline $\begin{array}{l}\text { Variety / Choice: the company provides } \\
\text { and makes available an appropriate } \\
\text { selection }\end{array}$ & $\begin{array}{l}114 \\
115 \\
116 \\
117 \\
118 \\
119\end{array}$ & $\begin{array}{l}\text { Appropriate degree of variety } \\
\text { Breadth of product range } \\
\text { Multi-tier service } \\
\text { Pick and choose } \\
\text { Provision of choice } \\
\text { Stock availability }\end{array}$ & $\sqrt{ }$ & $\begin{array}{l}\sqrt{ } \\
\sqrt{ } \\
\sqrt{ } \\
\sqrt{ } \\
\sqrt{ } \\
\sqrt{ }\end{array}$ \\
\hline
\end{tabular}

The final two columns indicate whether the construct emerged from the B2B data, the B2C data or both. 
Table 4:

\section{Key customer experience quality constructs - B2B}

\begin{tabular}{|c|c|c|c|c|}
\hline B2B Construct & Construct Pole & Contrast Pole & Definition & $A N V^{*}$ \\
\hline $\begin{array}{l}\text { 1. Extent of personal } \\
\text { contact }(\# 69)\end{array}$ & Personal contact & Impersonal contact & $\begin{array}{l}\text { The extent to which the company deals with the customer through personal contact methods. Some } \\
\text { companies deal with the customer via personal contact methods (e.g., face-to-face). By contrast, the } \\
\text { customer has no personal contact with the company (e.g., web-based or based on standardized } \\
\text { paperwork). }\end{array}$ & 12.06 \\
\hline 2. Flexibility (\#70) & Flexible & Inflexible & $\begin{array}{l}\text { The willingness and ability to modify the offering in response to the customer's specific needs or } \\
\text { changing requirements. Some companies are willing and able to modify the offering (flexible), } \\
\text { while others stick to a standardized approach and are unwilling to flex existing agreements } \\
\text { (inflexible). }\end{array}$ & 11.49 \\
\hline $\begin{array}{l}\text { 3. Implicit } \\
\text { understanding of } \\
\text { customer needs } \\
\text { (\#13) }\end{array}$ & $\begin{array}{l}\text { Deep understanding } \\
\text { of customer needs }\end{array}$ & $\begin{array}{l}\text { Poor } \\
\text { understanding of } \\
\text { customer needs }\end{array}$ & $\begin{array}{l}\text { The extent to which the supplier implicitly understands the needs of the customer in terms of the } \\
\text { nature of the business, the context within which the product or service is being delivered and the } \\
\text { specific requirements of the customer through the application of existing knowledge held within the } \\
\text { supplier. Some companies have a deep understanding of customer needs based on prior knowledge } \\
\text { (deep understanding), while for other companies, the customer has to explain the nature of the } \\
\text { business, the context, and the requirements (poor understanding). }\end{array}$ & 11.41 \\
\hline $\begin{array}{l}\text { 4. Concern to elicit } \\
\text { customer's } \\
\text { objectives (\#20) }\end{array}$ & $\begin{array}{l}\text { Proactive in eliciting } \\
\text { customer's objectives }\end{array}$ & $\begin{array}{l}\text { No attempt to elicit } \\
\text { customer's } \\
\text { objectives }\end{array}$ & $\begin{array}{l}\text { The extent to which the company actively seeks to elicit the objectives the customer has in } \\
\text { purchasing the product or service. Some companies are proactive in achieving this (proactive), while } \\
\text { others make no attempt to understand the customer's objectives (no attempt). }\end{array}$ & 11.03 \\
\hline $\begin{array}{l}\text { 5. Proactivity in } \\
\text { checking that } \\
\text { everything is OK } \\
(\# 26)\end{array}$ & $\begin{array}{l}\text { Proactively checking } \\
\text { that everything is } O K\end{array}$ & $\begin{array}{l}\text { Assuming that } \\
\text { everything is } O K\end{array}$ & $\begin{array}{l}\text { The extent to which the company proactively checks that everything is OK. Some companies are } \\
\text { proactive in checking that everything is OK (proactively checking that everything is OK), while } \\
\text { others assume that everything is OK (assuming that everything is OK). }\end{array}$ & 10.97 \\
\hline $\begin{array}{l}\text { 6. Promise } \\
\text { fulfillment (\#96) }\end{array}$ & Keеp promises & $\begin{array}{l}\text { Do not keep } \\
\text { promises }\end{array}$ & $\begin{array}{l}\text { The extent to which the company keeps promises they have made to the customer. Some companies } \\
\text { always keep promises they have made (keep promises), while others fail to keep their promises (do } \\
\text { not keep promises). }\end{array}$ & 10.63 \\
\hline 7. Knowledge (\#14) & $\begin{array}{l}\text { Possess knowledge } \\
\text { which can be applied } \\
\text { to add value }\end{array}$ & $\begin{array}{l}\text { Do not possess } \\
\text { knowledge }\end{array}$ & $\begin{array}{l}\text { The extent to which a company possesses the knowledge / expertise to add value to the customer. } \\
\text { Some companies possess knowledge / expertise and thereby add value to the customer (possess } \\
\text { knowledge which can be applied to add value), while others do not possess knowledge / expertise to } \\
\text { add value (do not possess knowledge). }\end{array}$ & 10.41 \\
\hline
\end{tabular}

* ANV: Average normalised variability (Goffin et al. 2006). 
Table 5:

Key customer experience quality constructs - B2C

\begin{tabular}{|c|c|c|c|c|}
\hline B2C Construct & Construct Pole & Contrast Pole & Definition & $A N V^{*}$ \\
\hline $\begin{array}{l}\text { 1. } \begin{array}{l}\text { Helpfulness } \\
(\# 23)\end{array}\end{array}$ & Helpful & Not helpful & $\begin{array}{l}\text { The extent to which the staff of the company are helpful. Some companies have staff for whom } \\
\text { nothing seems too much trouble in helping the customer (helpful), while other companies' staff } \\
\text { who seem unwilling to help the customer (not helpful). }\end{array}$ & 12.45 \\
\hline $\begin{array}{l}\text { Value for time } \\
(\# 113)\end{array}$ & $\begin{array}{l}\text { Company respects } \\
\text { and makes efficient } \\
\text { use of customer's } \\
\text { time }\end{array}$ & $\begin{array}{l}\text { Company does not } \\
\text { seem to care about } \\
\text { customer's time }\end{array}$ & $\begin{array}{l}\text { The extent to which the company demonstrates that they value, and attempt to make efficient use } \\
\text { of, the customer's time (for example, by shortening waiting times and delivering services } \\
\text { efficiently). Some companies appear to do everything in their power to use the customer's time } \\
\text { efficiently (company respects and makes efficient use of customer's time), while other companies } \\
\text { do not appear to care about using the customer's time efficiently (company does not seem to care } \\
\text { about customer's time). }\end{array}$ & 12.42 \\
\hline $\begin{array}{l}\text { Customer } \\
\text { recognition } \\
(\# 67)\end{array}$ & Recognize customer & $\begin{array}{l}\text { Do not notice the } \\
\text { Customer }\end{array}$ & $\begin{array}{l}\text { The extent to which customers feel they are recognized and acknowledged when they initiate } \\
\text { contact. Some companies appear to recognize and acknowledge customers when they initiate } \\
\text { contact with the company (recognize customer), while others do not appear to notice or } \\
\text { acknowledge the customer (do not notice the customer). }\end{array}$ & 12.12 \\
\hline $\begin{array}{l}\text { 4. Promise } \\
\text { fulfillment } \\
(\# 96)\end{array}$ & Keep promises & $\begin{array}{l}\text { Do not keep } \\
\text { promises }\end{array}$ & $\begin{array}{l}\text { The extent to which the company keeps promises they have made to the customer. Some } \\
\text { companies always keep promises they have made (keep promises), while others fail to keep their } \\
\text { promises (do not keep promises). }\end{array}$ & 11.39 \\
\hline $\begin{array}{l}\text { 5. Interest in } \\
\text { problem solving } \\
(\# 25)\end{array}$ & $\begin{array}{l}\text { Try to resolve } \\
\text { customer problem }\end{array}$ & $\begin{array}{l}\text { Are not interested } \\
\text { in customer } \\
\text { problem }\end{array}$ & $\begin{array}{l}\text { The extent to which customers feel that the staff try to resolve their problems. Some companies' } \\
\text { staff appear to take ownership of the problem and try to help to find a solution for the customer } \\
\text { (try to resolve customer problem), while others do not seem to be interested in the customers' } \\
\text { problems (are not interested in customer problem or they argue). }\end{array}$ & 11.31 \\
\hline $\begin{array}{l}\text { 6. Personalization } \\
(\# 71)\end{array}$ & $\begin{array}{l}\text { Personalized } \\
\text { treatment of customer }\end{array}$ & $\begin{array}{l}\text { Anonymous } \\
\text { treatment of } \\
\text { customer }\end{array}$ & $\begin{array}{l}\text { The extent to which the customer feels treated in a personalized way. Some companies appear to } \\
\text { know the customer as an individual and personalize the service delivery (personalized treatment of } \\
\text { customer), while others seem to treat the customer anonymously (anonymous treatment of } \\
\text { customer). }\end{array}$ & 10.88 \\
\hline $\begin{array}{l}\text { 7. Competence } \\
(\# 11)\end{array}$ & Competent & Incompetent & $\begin{array}{l}\text { The extent to which the customer feels that staff know what they are doing and they are competent } \\
\text { in doing their job. Some staff inspire confidence in customers that they know what they are doing } \\
\text { and are able to do their job properly (competent), while others appear to be inept and are not able } \\
\text { to perform their job in a way that is required of them (incompetent). }\end{array}$ & 10.83 \\
\hline $\begin{array}{l}\text { 8. Accessibility of } \\
\text { person / facility } \\
(\# 2)\end{array}$ & High ease of access & Difficult to access & $\begin{array}{l}\text { The extent to which the customer finds it easy to access an appropriate person and/or facility (e.g., } \\
\text { webpage, store). Some companies make it easy for customers to access the appropriate person } \\
\text { and/or facility (high ease of access), while other companies make it difficult for customers to } \\
\text { access their people or facilities (difficult to access). }\end{array}$ & 10.56 \\
\hline
\end{tabular}

* ANV: Average normalized variability (Goffin et al. 2006). 
FIGURES

Figure 1:

Conceptual model of customer experience quality

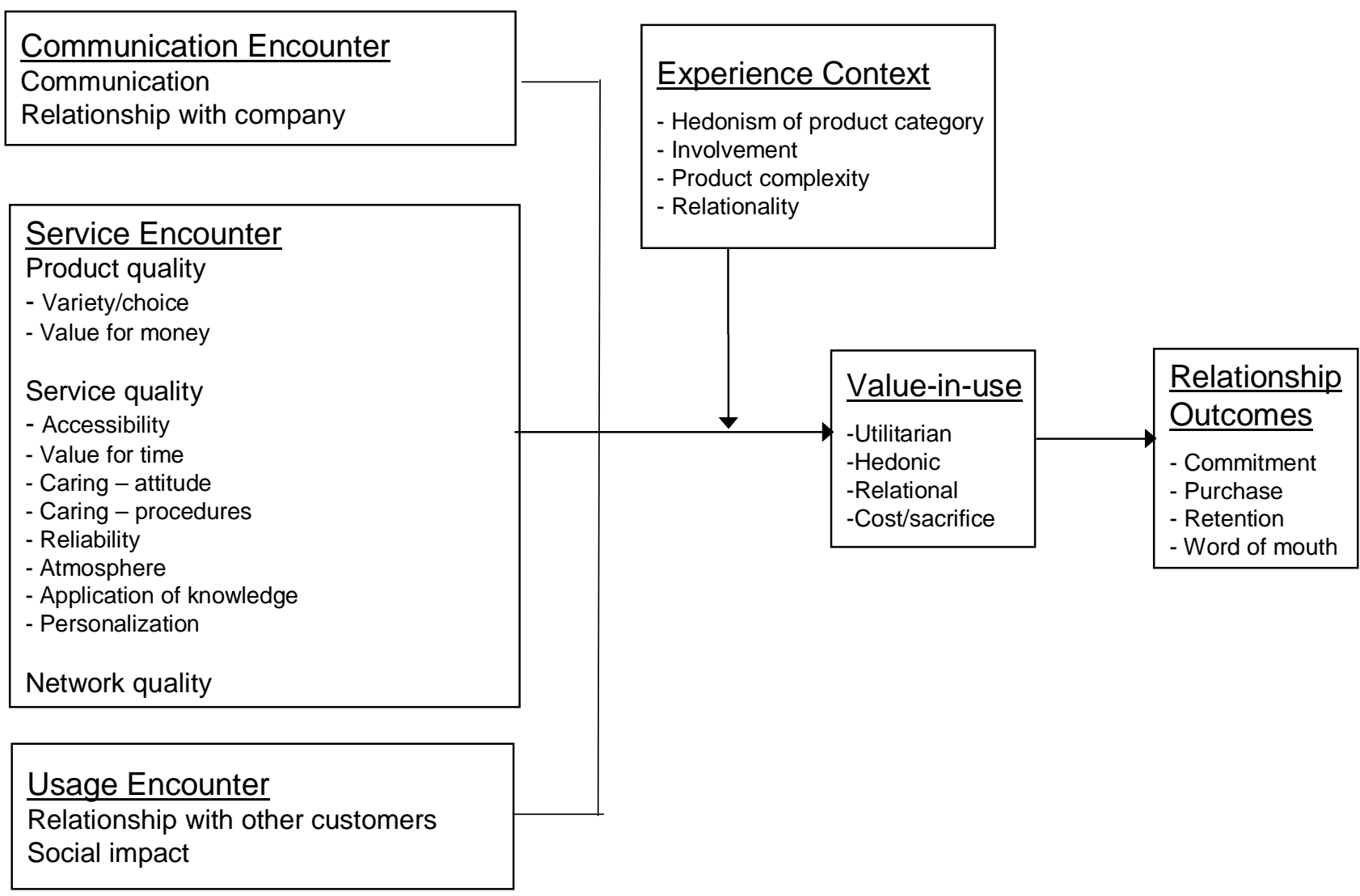




\section{References}

Aaker, J., Fournier, S., \& Brasal, S.A. (2004). When good brands do bad. Journal of Consumer Research, 31(1), 1-16.

Aggarwal, P. (2004). The effects of brand relationship norms on consumer attitudes and behavior. Journal of Consumer Research, 31, 87-101.

Anderson, E. W., Fornell, C., \& Rust, R. T. (1997). Customer satisfaction, productivity, and profitability: Differences between goods and services. Marketing Science, 16, 129-144.

Arnold, M. J., Reynolds, K. E., Ponder, N., \& Lueg, J. E. (2005). Customer delight in a retail context: Investigating delightful and terrible shopping experiences. Journal of Business Research, 58, 1132-1145.

Arnould, E. J., \& Price, L. L. (1993). River magic: Extraordinary experience and the extended service encounter. Journal of Consumer Research, 20, 24-45.

Bargh, J.A. (1992). Does subliminality matter to social psychology? Awareness of the stimulus versus awareness of its influence. In Bornstein, R.F. \& Pittman, T.S. (Eds.), Perception without awareness: Cognitive clinical and social perspectives. New York: Guilford Press.

Barsalou, L. (1991). Deriving categories to achieve goals. In Bower, G.H. (Ed.), The psychology of learning and motivation: Advances in research and theory. New York: Academic Press.

Baumeister, R. F., Vohs, K. D., DeWall, C. N., \& Zhang, L. (2007). How emotion shapes behavior: Feedback, anticipation, and reflection, rather than direct causation. Personality and Social Psychology Review, 11, 167-203.

Bender, M. P. (1974). Providing versus elicited constructs - An explanation of Warr and Coffman's anomalous finding. British Journal of Social and Clinical Psychology, 13, 329-330.

Berry, L. L., Carbone, L. P., \& Haeckel, S. H. (2002). Managing the total customer experience. MIT Sloan Management Review, 43(3), 85-89.

Bolton, R. N., \& Drew, J. H. (1991). A multistage model of customers' assessments of service quality and value. Journal of Consumer Research, 17, 375-384.

Bolton, R. N., Lemon, K. N., \& Verhoef, P. (2008). Expanding business-to-business customer relationships: Modeling the customer's upgrade decision. Journal of Marketing, $72,46-64$. 
Bowman, D. \& Narayandas, D. (2004) Linking customer management effort to customer profitability in business markets. Journal of Marketing Research, 41, 433-447.

Brakus, J. J., Schmitt, B. H., \& Zarantonello, L. (2009). Brand experience: What is it? How is it measured? Does it affect loyalty? Journal of Marketing, 73, 52-68.

Briggs, E., \& Grisaffe, D. (2010). Service performance loyalty intentions in a business-tobusiness context: The role of relational exchange outcomes and customer characteristics. Journal of Service Research, 13(1), 37-51.

Brown, C. A., \& Detoy, C. J. (1988). A comparison of the personal constructs of management in new and experienced managers. In P. Banyard \& A. Grayson (Eds.), Introducing psychological research: Sixty studies that shape psychology (pp. 426-432). London, UK: Macmillan.

Burr, V., \& Butt, T. (1992). Invitation to personal construct psychology. London: Whurr.

Caruana, A., Money, A.H., \& Berthon, P.R. (2000) Service quality and satisfaction: the moderating role of value. European Journal of Marketing, 34(11/12), 1338-1353.

Chitturi, R., Raghunathan, R., \& Mahajan, V. (2008). Delight by design: The role of hedonic versus utilitarian benefits. Journal of Marketing, 72, 48-63.

Cova, B., \& Salle, R. (2008). Marketing solutions in accordance with the S-D logic: Cocreating value with customer network actors. Industrial Marketing Management, 37, 270277.

Coviello, N. E., Brodie, R. J., Danaher, P. J., \& Johnston, W. J. (2002). How firms relate to their markets: An empirical examination of contemporary marketing practices. Journal of Marketing, 66, 33-46.

Cowley, E. (2008). Looking back at an experience through rose-colored glasses. Journal of Business Research, 61, 1046-1052.

Cropanzano, R., \& Mitchell, M. S. (2005). Social exchange theory: An interdisciplinary review. Journal of Management, 31, 874-900.

De Canniere, M. H., De Pelsmacker, P., \& Geuens, M. (2009). Relationship Quality and the Theory of Planned Behavior models of behavioral intentions and purchase behavior. Journal of Business Research, 62, 82-92.

De Wulf, K., \& Odekerken-Schroder, G. (2003). Assessing the impact of a retailer's relationship efforts on consumers' attitudes and behaviors. Journal of Retailing, 10, 95108.

Deighton, J. (1992). The consumption of performance. Journal of Consumer Research, 19, 362-373. 
Diamond, N., Sherry, J. F. Jr., Muñiz, A. M. Jr., McGrath, M. A., Kozinets, R. V., \& Borghini, S. (2009). American Girl and the brand gestalt: Closing the loop on sociocultural branding research. Journal of Marketing, 73, 118-134.

Dorsch, M.J., Swanson, S.R., \& Kelley, S.W. (1998). The role of relationship quality in the stratification of vendors as perceived by customers. Journal of the Academy of Marketing Science, 26(2), 128-142.

Fang, E., Palmatier, R. W., \& Evans, K. R. (2008). Influence of customer participation on creating and sharing of new product value. Journal of the Academy of Marketing Science, $36,322-366$.

Fisk, R., Brown, S. W., \& Bitner, M. J. (1993). Tracking the evolution of services marketing literature. Journal of Retailing, 69, 61-103.

Fransella, F. \& Bannister, D. (1977). A manual for repertory grid technique. London, UK: Academic Press.

Frow, P., \& Payne, A. (2007) Towards the 'perfect' customer experience. Journal of Brand Management, 15, 89-101.

Gammack, J. G., \& Stephens, R. A. (1994). Repertory grid technique in constructive interaction. In C. Cassell \& G. Symon (Eds.), Qualitative methods in organizational research: A practical guide (pp. 72-90). London: Sage.

Gentile, C., Spiller, N., \& Noci, G. (2007). How to sustain the customer experience: An overview of experience components that co-create value with the customer. European Management Journal, 25, 395-410.

Gilmore, J. H., \& Pine, B. II. (2002). Customer experience places: The new offering frontier. Strategy \& Leadership, 30, 4-11.

Goffin, K. (2002). Repertory grid technique. In D. Partington (Ed.), Essential skills for management research (pp. 199-225). London, UK: Sage.

Goffin, K. \& Koners, U. (2011). Tacit knowledge, lessons learned and new product development. Accepted for publication in the Journal of Product Innovation Management, 28(2).

Goffin, K., Lemke F., \& Szwejczewski, M. (2006). An exploratory study of 'close' suppliermanufacturer relationships. Journal of Operations Management, 25, 189-209.

Grewal, D., Levy, M., \& Kumar, V. (2009). Customer experience management in retailing: An organizing framework. Journal of Retailing, 85, 1-14.

Grönroos, C. (2000). Service management and marketing: A customer relationship management approach. Chichester, UK: Wiley. 
Grove, S. J., \& Fisk, R. P. (1997). The impact of other customers on service experiences: A critical incident examination of "getting along". Journal of Retailing, 73, 63-85.

Gwinner, K.P., Gremler, D.D., \& Bitner, M.J. (1998). Relational benefits in services industries: The customer's perspective. Journal of the Academy of Marketing Science, 26(2), 101-114.

Holbrook, M. B. (2006). ROSEPEKICECIVECI versus CCV. In R.F. Lusch \& S.L. Vargo (Eds.), The service-dominant logic of marketing: Dialog, debate, and directions (pp. 208221). Armonk, NY: Sharpe.

Homburg, C., Wieseke, J. \& Bornemann, T. (2009). Implementing the marketing concept at the employee-customer interface: The role of customer need knowledge. Journal of Marketing, 73, 64-81.

Hussey, J., \& Hussey, R. (1997). Business research. London, UK: Macmillan Press. Jankowicz, D. (2004). The easy guide to repertory grids. Chichester, UK: Wiley.

Kelly, G. A. (1955). The psychology of personal constructs: Volume one - a theory of personality. London, UK: Routledge.

Kelly, G. A. (1963). A theory of personality: The psychology of personal constructs. London: Norton.

Kohli, A. K., \& Jaworski, B. J. (1990) Market orientation: The construct, research propositions, and managerial implications. Journal of Marketing, 54, 1-18.

Kwortnik, R. J., \& Ross, W. T. (2007). The role of positive emotions in experiential decisions. International Journal of Research in Marketing, 24, 324-335.

La, V., Patterson, P., \& Styles, C. (2009). Client-perceived performance and value in professional B2B services: An international perspective. Journal of International Business Studies, 40, 274-300.

Lemke, F., Keith G., \& Szwejczewski, M. (2003). Investigating the meaning of suppliermanufacturer partnerships: An exploratory study. International Journal of Physical Distribution \& Logistics Management, 33, 12-35.

Levy, L. H., \& Dugan, R. D. (1956). A factorial study of personal constructs. Journal of Consulting Psychology, 20, 53-57.

Macdonald, E. K., Wilson, H. N., Martinez, V., \& Toosi, A. (2009). Assessing the value-inuse of integrated product-service offerings: A repertory grid approach. Frontiers in Service conference, Hawaii, October. 
McColl-Kennedy, J. R., Vargo, S. L., Dagger, T., \& Sweeney, J. C. (2009). Customers as resource integrators: Styles of customer co-creation. Naples Forum on Services, Capri, June.

Meyer, C., \& Schwager, A. (2007). Understanding customer experience. Harvard Business Review, February, 117-126.

Narver, J. C., \& Slater, S. F. (1990). The effect of a market orientation on business profitability. Journal of Marketing, 54, 20-35.

Neely, A. (2008). Exploring the financial consequences of the servitization of manufacturing. Operations Management Research, 1, 103-118.

Neu, W.A., \& Brown, S.W. (2005). Forming successful business-to-business services in goods-dominant firms. Journal of Service Research, 8(1), 3-17.

Oliver, R. (1999). Value as excellence in the consumption experience. In M. Holbrook (Ed.), Consumer value: A framework for analysis and research (pp. 43-62). London, UK: Routledge.

Palmatier, R.W., Scheer, L.K., Evans, K.R., \& Arnold, T.J. (2008). Achieving relationship marketing effectiveness in business-to-business exchanges. Journal of the Academy of Marketing Science, 36, 174-190.

Parasuraman, A., Zeithaml, V. A., \& Berry, L. L. (1985). A conceptual model of service quality and its implications for future research. Journal of Marketing, 49, 41-50.

Parasuraman, A., Zeithaml, V. A., \& Berry, L. L. (1988). SERVQUAL: A multiple-item scale for measuring consumer perceptions of service quality. Journal of Retailing, 64, $12-$ 40 .

Payne, A., Storbacka, K., \& Frow, P. (2008). Managing the co-creation of value. Journal of the Academy of Marketing Science, 36, 83-96.

Peterman, M. L. (1997). The effects of concrete and abstract consumer goals on information processing. Psychology and Marketing, 14, 561-583.

Puccinelli, N. M., Goodstein, R. C., Grewal, D., Price, R., Raghubir, P., \& Stewart, D. (2009). Customer experience management in retailing: Understanding the buying process. Journal of Retailing, 85, 15-30.

Pullman, M. E., \& Gross, M. A. (2004). Ability of experience design elements to elicit emotions and loyalty behaviors. Decision Sciences, 35, 551-578.

Raghubir, P., \& Corfman, K. (1999). When do price promotions affect pretrial brand evaluations? Journal of Marketing Research, 36(2), 211-22. 
Reinartz, W., \& Ulaga, W. (2008). How to sell services more profitably. Harvard Business Review, 86, 90-96.

Ritchins, M. L. (1994). Valuing things: The public and private meanings of possessions. Journal of Consumer Research, 21, 504-521.

Rohm, A.J., \& Swaminathan, V. (2004). A typology of online shoppers based on shopping motivation. Journal of Business Research, 57, 748-57.

Rust, R. T., \& Thompson, D. V. (2006). How does marketing strategy change in a servicebased world? Implications and directions for research. In R. F. Lusch \& S. L. Vargo (Eds.), The service-dominant logic of marketing: Dialog, debate, and directions (pp. 381392). Armonk, NY: Sharpe.

Ryals, L. (2005). Making customer relationship management work: The measurement and profitable management of customer relationships. Journal of Marketing, 69, 252-261.

Sanchez-Fernandez, R., Iniesta-Bonillo, M.A., \& Holbrook, M.B. (2009). The conceptualisation and measurement of consumer value in services. International Journal of Market Research, 51, 93-113.

Sautter, P., Hyman, M. R., \& Lukosius, V. (2004). E-tail atmospherics: A critique of the literature and model extension. Journal of Electronic Commerce Research, 5, 14-24.

Schau, H. J., Muñiz, A. M. Jr., \& Arnould, E. J. (2009). How brand community practices create value. Journal of Marketing, 73, 30-51.

Schembri, S. (2009). Reframing brand experience: the experiential meaning of HarleyDavidson. In press for Journal of Business Research, doi:10.1016/j.jbusres.2008.11.004.

Schmitt, B. (1999). Experiential marketing: How to get customers to sense, feel, think, act and relate to your company and brands. New York: Free Press.

Schouten, J. W., McAlexander, J. H., \& Koenig, H. F. (2007). Transcendent customer experience and brand community. Journal of the Academy of Marketing Science, 35, 357-368.

Seddon, J. \& Sant, R. (2007). Increasing business value through improved customer experiences. E-Perspectives, December. Retrieved October 22, 2009 from http://www.millwardbrown.com.

Sengupta, J., Goodstein, R. C., \& Boninger, D. S. (1997). All cues are not created equal: Obtaining attitude persistence under low-involvement conditions. Journal of Consumer Research, 23, 351-356.

Shaw, C. (2002). The DNA of customer experience: How emotions drive value. New York: Palgrave. 
Smith, J. A. (1995). Repertory grids: An interactive, case-study perspective. In J. A. Smith, R. Harré \& L. V. Langenhove (Eds.), Rethinking Methods in Psychology (pp. 162-177). London, UK: Sage.

Smith, A.K., Bolton, R.N., \& Wagner, J. (1999). A model of customer satisfaction with service encounters involving failure and recovery. Journal of Marketing Research, 36, 356-372.

Sousa, R., \& Voss, C. A. (2006). Service quality in multichannel services employing multiple channels. Journal of Service Research, 8, 356-371.

Stuart, F. I., \& Tax, S. (2004). Toward an integrative approach to designing service experiences: Lessons learned from the theatre. Journal of Operations Management, 22, 609-627.

Sweeney, J. C., \& Soutar, G. N. (2001). Consumer perceived value: the development of a multiple item scale. Journal of Retailing, 77, 203-220.

Swinyard, W. R. (1993). The effects of mood, involvement, and quality of store experience on shopping intentions. Journal of Consumer Research, 20, 271-80.

Szwejczewski, M., Lemke, F., \& Goffin, K. (2005). Manufacturer-supplier relationships: An empirical study of German manufacturing companies. Journal of Operations and Production Management, 25, 875-897.

Szwejczewski, M., Goffin, K., Lemke, F., Pfeiffer, R., \& Lohmüller, B. (2001). Supplier management in German manufacturing companies: An empirical investigation. International Journal of Physical Distribution \& Logistics Management, 31, 354-373.

Tax, S.S., Brown, S.W., \& Chandrashekaran, M. (1998). Customer evaluations of service complaint experiences: Implications for relationship marketing. Journal of Marketing, $62,60-76$.

Thakor, M., Suri, R., \& Saleh, K. (2008). Effects of service setting and other consumers' age on the service perceptions of young consumers. Journal of Retailing, 84, 137-249.

Tindall, C. (1994). Personal construct approaches. In P. Banister, E. Burman, I. Parker, M. Taylor \& C. Tindall (Eds.), Qualitative methods in psychology: A research guide (pp. 7291). Buckingham: Open University Press.

Trope, Y. (1986). Identification and inferential processes in dispositional attribution. Psychological Review, 93(3), 239-67.

Tuli, K. R., Kohli, A. K., \& Bharadwaj, S. G. (2007). Rethinking customer solutions: From product bundles to relational processes. Journal of Marketing, 71, 1-17. 
Tynan, C., McKechnie, S., \& Chhuon, C. (2010). Co-creating value for luxury brands. In press for Journal of Business Research, doi:10.1016/j.jbusres.2009.10.012.

Vargo, S. L., \& Lusch, R. F. (2004). Evolving to a new dominant logic of marketing. Journal of Marketing, 68, 1-17.

Vargo, S. L., \& Lusch, R. F. (2008). Service-dominant logic: Continuing the evolution. Journal of the Academy of Marketing Science, 36, 1-10.

Vargo, S. L., Maglio, P. P., \& Akaka, M. A. (2008). On value and value co-creation: A service systems and service logic perspective. European Management Journal, 26, 145152.

Verhoef, P., Lemon, K. N., Parasuraman, A., Roggeveen, A., Tsiros, M., \& Schlesinger, L. A. (2009). Customer experience creation: Determinants, dynamics and management strategies. Journal of Retailing, 85, 31-41.

Voss, C., Roth, A. V., \& Chase, R. B. (2008). Experience, service operations strategy, and services as destinations: Foundations and exploratory investigation. Production and Operations Management, 17, 247-266.

Walter, A., Müller, T.A., Helfert, G., \& Ritter, T. (2003). Functions of industrial supplier relationships and their impact on relationship quality. Industrial Marketing Management, 32, 159-169.

Ward, J. C., \& Ostrum, A. L. (2006). Complaining to the masses: The role of protest framing in customer-created complaint web sites. Journal of Consumer Research, 33, 220-230.

Woodruff, R. B. (1997). Customer value: The next source for competitive advantage. Journal of the Academy of Marketing Science, 25, 139-153.

Woodruff, R. B., \& Flint, D. (2006). Marketing's service-dominant logic and customer value. In R. F. Lusch \& S. L. Vargo (Eds.), The service-dominant logic of marketing: Dialog, debate, and directions (pp. 183-195). Armonk, NY: Sharpe.

Zeithaml, V. (1988). Consumer perceptions of price, quality, and value: A means-end model and synthesis of evidence. Journal of Marketing, 52, 2-22.

Zeithaml, V. A., Berry, L. L., \& Parasuraman, A. (1996). The behavioral consequences of service quality. Journal of Marketing, 60, 31-46. 